University of Nebraska - Lincoln

DigitalCommons@University of Nebraska - Lincoln

\title{
Estimation of Net Ecosystem Carbon Exchange for the Conterminous United States by Combining MODIS and AmeriFlux Data
}

Jingfeng Xiao

Purdue University, West Lafayette, IN

Qianlai Zhuang

Purdue University, West Lafayette, IN

Dennis D. Baldocchi

University of California, Berkeley, baldocchi@berkeley.edu

Beverly E. Law

Oregon State University, bev.law@oregonstate.edu

Andrew P. Richardson University of New Hampshire, Durham, arichardson@oeb.harvard.edu

Part of the Natural Resources and Conservation Commons

See next page for additional authors

Xiao, Jingfeng; Zhuang, Qianlai; Baldocchi, Dennis D.; Law, Beverly E.; Richardson, Andrew D.; Chen, Jiquan; Oren, Ram; Starr, Gregory; Noormets, Asko; Ma, Siyan; Verma, Shashi; Wharton, Sonia; Wofsy, Steven C.; Bolstad, Paul V.; Burns, Sean P.; Cook, David R.; Curtis, Peter S.; Drake, Bert G.; Falk, Matthias; Fischer, Marc L.; Foster, David R.; Gu, Lianhong; Hadley, Julian L.; Hollinger, David Y.; Katul, Gabriel G.; Litvak, Marcy; Martin, Timothy A.; Matamala, Roser; McNulty, Steve; Meyers, Tilden P.; Monson, Russell K.; Munger, J. William; Oechel, Walter C.; Tha Paw U, Kyaw; Schmid, Hans Peter; Scott, Russell L.; Sun, Ge; Suyker, Andrew E.; and Torn, Margaret S., "Estimation of Net Ecosystem Carbon Exchange for the Conterminous United States by Combining MODIS and AmeriFlux Data" (2008). Papers in Natural Resources. 147.

https://digitalcommons.unl.edu/natrespapers/147

This Article is brought to you for free and open access by the Natural Resources, School of at DigitalCommons@University of Nebraska - Lincoln. It has been accepted for inclusion in Papers in Natural Resources by an authorized administrator of DigitalCommons@University of Nebraska - Lincoln. 


\section{Authors}

Jingfeng Xiao, Qianlai Zhuang, Dennis D. Baldocchi, Beverly E. Law, Andrew D. Richardson, Jiquan Chen, Ram Oren, Gregory Starr, Asko Noormets, Siyan Ma, Shashi Verma, Sonia Wharton, Steven C. Wofsy, Paul V. Bolstad, Sean P. Burns, David R. Cook, Peter S. Curtis, Bert G. Drake, Matthias Falk, Marc L. Fischer, David R. Foster, Lianhong Gu, Julian L. Hadley, David Y. Hollinger, Gabriel G. Katul, Marcy Litvak, Timothy A. Martin, Roser Matamala, Steve McNulty, Tilden P. Meyers, Russell K. Monson, J. William Munger, Walter C. Oechel, Kyaw Tha Paw U, Hans Peter Schmid, Russell L. Scott, Ge Sun, Andrew E. Suyker, and Margaret S. Torn 


\section{Estimation of net ecosystem carbon exchange for the conterminous United States by combining MODIS and Ameriflux data}

Jingfeng Xiao ${ }^{a, *, 1}$, Qianlai Zhuang ${ }^{b}$, Dennis D. Baldocchi ${ }^{c}$, Beverly E. Law ${ }^{d}$, Andrew D. Richardson ${ }^{e}$, Jiquan Chen ${ }^{f}$, Ram Oren ${ }^{g}$, Gregory Starr ${ }^{h}$, Asko Noormets ${ }^{i}$, Siyan $\mathrm{Ma}^{\mathrm{c}}$, Shashi B. Verma ${ }^{j}$, Sonia Wharton ${ }^{k}$, Steven C. Wofsy ${ }^{l}$, Paul V. Bolstad ${ }^{m}$, Sean P. Burns ${ }^{n}$, David R. Cook ${ }^{\circ}$, Peter S. Curtis ${ }^{p}$, Bert G. Drake ${ }^{q}$, Matthias Falk ${ }^{k}$, Marc L. Fischer ${ }^{r}$, David R. Foster ${ }^{s}$, Lianhong $\mathrm{Gu}^{t}$, Julian L. Hadley ${ }^{u}$, David Y. Hollinger ${ }^{v}$, Gabriel G. Katul ${ }^{g}$, Marcy Litvak ${ }^{w}$, Timothy A. Martin ${ }^{x}$, Roser Matamala ${ }^{y}$, Steve McNulty ${ }^{z}$, Tilden P. Meyers ${ }^{A}$, Russell K. Monson ${ }^{n}$, J. William Munger ${ }^{B}$, Walter C. Oechel ${ }^{C}$, Kyaw Tha Paw $U^{k}$, Hans Peter Schmid ${ }^{D, E}$, Russell L. Scott ${ }^{F}$, Ge Sun $^{z}$, Andrew E. Suyker ${ }^{j}$, Margaret S. Torn ${ }^{\mathrm{G}}$

${ }^{a}$ Department of Earth \& Atmospheric Sciences, Purdue Climate Change Research Center, Purdue University, West Lafayette, IN 47907, USA

${ }^{\mathrm{b}}$ Department of Earth \& Atmospheric Sciences, Department of Agronomy, Purdue Climate Change Research Center, Purdue University, West Lafayette, IN 47907, USA

'Ecosystem Science Division, Department of Environmental Science, Policy and Management, University of California, Berkeley, CA 94720, USA

${ }^{\mathrm{d}}$ College of Forestry, Oregon State University, Corvallis, OR 97331, USA

e Complex Systems Research Center Institute for the Study of Earth, Oceans and Space, University of New Hampshire, Durham, NH 03824, USA

${ }^{\mathrm{f}}$ Department of Environmental Sciences, University of Toledo, Toledo, $\mathrm{OH} 43606$, USA

${ }^{g}$ Nicholas School of the Environment, Duke University, Durham, NC 27708, USA

${ }^{\mathrm{h}}$ Department of Biological Sciences, University of Alabama, Tuscaloosa, AL 35487, USA

${ }^{\mathrm{i}}$ Department of Forestry and Environmental Resources and Southern Global Change Program, North Carolina State University, Raleigh, NC 27695, USA

${ }^{j}$ School of Natural Resources, University of Nebraska-Lincoln, Lincoln, NE 68583, USA

${ }^{\mathrm{k}}$ Department of Land, Air and Water Resources, University of California, Davis, CA 95616, USA

${ }^{1}$ Division of Engineering and Applied Science/Department of Earth and Planetary Science, Harvard University, Cambridge, MA 02138, USA

${ }^{m}$ Department of Forest Resources, University of Minnesota, St. Paul, MN 55108, USA

${ }^{\mathrm{n}}$ Department of Ecology and Evolutionary Biology, University of Colorado, Boulder, CO 80309, USA

${ }^{\circ}$ Argonne National Laboratory, Environmental Science Division, Argonne, IL 60439, USA

${ }^{\mathrm{p}}$ Department of Evolution, Ecology, and Organismal Biology, Ohio State University, Columbus, OH 43210, USA

${ }^{\mathrm{q}}$ Smithsonian Environmental Research Center, Edgewater, MD 21037, USA

${ }^{\mathrm{r}}$ Lawrence Berkeley National Laboratory, Environmental Energy Technologies Division, Atmospheric Science Department, Berkeley, CA 94720, USA

${ }^{\mathrm{s}}$ Harvard Forest and Department of Organismic and Evolutionary Biology, Harvard University, Petersham, MA 01366, USA

${ }^{t}$ Oak Ridge National Laboratory Environmental Sciences Division, Oak Ridge, TN 37831, USA

${ }^{\mathrm{u}}$ Harvard Forest, Harvard University, Petersham, MA 01366, USA

\footnotetext{
* Corresponding author. Tel.: +1 8148659617.

E-mail address: jing@psu.edu (J. Xiao).

${ }^{1}$ Present address: Department of Meteorology, Pennsylvania State University, University Park, State College, PA 16802.
} 
v USDA Forest Service, Northeastern Research Station, Durham, NH 03824, USA

${ }^{\mathrm{w}}$ Department of Biology, University of New Mexico, Albuquerque, NM 87131, USA

${ }^{\mathrm{x}}$ University of Florida, Gainesville, FL 32611, USA

y Argonne National Laboratory, Biosciences Division, Argonne, IL 60439, USA

${ }^{\mathrm{z}}$ USDA Forest Service, Southern Research Station, Raleigh, NC 27606, USA

${ }^{A}$ NOAA/ARL, Atmospheric Turbulence and Diffusion Division, Oak Ridge, TN 37831, USA

${ }^{B}$ Department of Earth and Planetary Sciences, Harvard University, Cambridge, MA 02138, USA

${ }^{C}$ Department of Biology, San Diego State University, San Diego, CA 92182, USA

D Department of Geography, Indiana University, Bloomington, IN 47405, USA

${ }^{\mathrm{E}}$ Atmospheric Environmental Research, Institute of Meteorology and Climate Research, Research Center Karlsruhe (FZK/IMK-IFU), Kreuzeckbahnstr. 19, 82467 Garmisch-Partenkirchen, Germany

F USDA-ARS Southwest Watershed Research Center, Tucson, AZ 85719, USA

${ }^{G}$ Lawrence Berkeley National Laboratory, Earth Science Division, Berkeley, CA 94720, USA

\section{A R T I C L E I N F O}

Article history:

Received 22 March 2008

Received in revised form

23 June 2008

Accepted 26 June 2008

\section{Keywords:}

Net ecosystem carbon exchange MODIS

AmeriFlux

NEE

Regression tree

Eddy covariance

\begin{abstract}
A B S T R A C T
Eddy covariance flux towers provide continuous measurements of net ecosystem carbon exchange (NEE) for a wide range of climate and biome types. However, these measurements only represent the carbon fluxes at the scale of the tower footprint. To quantify the net exchange of carbon dioxide between the terrestrial biosphere and the atmosphere for regions or continents, flux tower measurements need to be extrapolated to these large areas. Here we used remotely sensed data from the Moderate Resolution Imaging Spectrometer (MODIS) instrument on board the National Aeronautics and Space Administration's (NASA) Terra satellite to scale up AmeriFlux NEE measurements to the continental scale. We first combined MODIS and AmeriFlux data for representative U.S. ecosystems to develop a predictive NEE model using a modified regression tree approach. The predictive model was trained and validated using eddy flux NEE data over the periods 2000-2004 and 2005-2006, respectively. We found that the model predicted NEE well $(r=0.73, p<0.001)$. We then applied the model to the continental scale and estimated NEE for each $1 \mathrm{~km} \times 1 \mathrm{~km}$ cell across the conterminous U.S. for each 8-day interval in 2005 using spatially explicit MODIS data. The model generally captured the expected spatial and seasonal patterns of NEE as determined from measurements and the literature. Our study demonstrated that our empirical approach is effective for scaling up eddy flux NEE measurements to the continental scale and producing wall-to-wall NEE estimates across multiple biomes. Our estimates may provide an independent dataset from simulations with biogeochemical models and inverse modeling approaches for examining the spatiotemporal patterns of $\mathrm{NEE}$ and constraining terrestrial carbon budgets over large areas.
\end{abstract}

\section{Introduction}

Net ecosystem carbon exchange (NEE), the difference between photosynthetic uptake and release of carbon dioxide $\left(\mathrm{CO}_{2}\right)$ by respiration from autotrophs (plants) and heterotrophs (e.g., microbial decomposition), represents the net exchange of $\mathrm{CO}_{2}$ between terrestrial ecosystems and the atmosphere (Law et al., 2006). The quantification of NEE for regions, continents, or the globe can improve our understanding of the feedbacks between the terrestrial biosphere and the atmosphere in the context of global change and facilitate climate policy-making.

To date, several techniques have been used to estimate NEE (Baldocchi et al., 2001). Atmospheric inverse models (e.g., Tans et al., 1990; Denning et al., 1996; Fan et al., 1998; Gurney et al., 2002; Deng et al., 2007), biogeochemical models (e.g., Potter et al., 1993; Running and Hunt, 1993; Field et al., 1995; Zhuang et al., 2003), and inventory approaches (e.g., Pacala et al., 2001; Goodale et al., 2002) have been used to infer net exchange of
$\mathrm{CO}_{2}$ and provide aggregated information on NEE over large areas during the past two decades. The accuracy of the estimates by atmospheric inverse models is limited by the sparseness of the $\mathrm{CO}_{2}$ observation network and their biased placement in the marine boundary layers (Tans et al., 1990; Denning et al., 1996; Fan et al., 1998). Moreover, this approach does not provide information about which ecosystems are contributing to the sinks/sources or the processes involved (Janssens et al., 2003). Most biogeochemical models, however, are dependent on site level parameterizations, which may limit the accuracy of model simulations over large areas. Inventory approaches provide information on NEE at multiyear to decadal timescales, and therefore do not provide information on seasonal and interannual variability of NEE and shorter-term physiological mechanisms (Baldocchi et al., 2001).

At the site level, eddy covariance flux towers have been providing continuous measurements of ecosystem level exchanges of carbon at half-hourly or hourly time steps since 
the early 1990s (Wofsy et al., 1993; Baldocchi et al., 2001). At present, over 400 eddy covariance flux towers are operating on a long-term and continuous basis over the globe (FLUXNET, 2008). This global network encompasses a large range of climate and biome types (Baldocchi et al., 2001), and provides the longest, most extensive, and most reliable measurements of NEE. However, these measurements only represent the fluxes from the scale of the tower footprint (Running et al., 1999) up to several square kilometers (Schmid, 1994; Göckede et al., 2008). To quantify the net exchange of $\mathrm{CO}_{2}$ between the terrestrial biosphere and the atmosphere, we need to scale these flux tower measurements to regions, continents, or the globe.

Satellite remote sensing is a potentially valuable tool for scaling eddy flux NEE measurements to large areas (Running et al., 1999). There have been several studies developing methods for integration of flux data with remote sensing data to quantify NEE over large areas. For example, Yamaji et al. (2007) linked Moderate Resolution Imaging Spectroradiometer (MODIS) data to eddy flux NEE data for regional extrapolation to deciduous broadleaf forests over Japan. Wylie et al. (2007) estimated NEE for grasslands in the northern Great Plains using satellite data from the SPOT (Satellite Pour l'Observation de la Terre) VEGETATION sensor and eddy flux NEE measurements. Papale and Valentini (2003) estimated NEE for European forests using flux tower data and satellite data derived from the Advanced Very High Resolution Radiometer (AVHRR). Despite these efforts, to our knowledge, no study has scaled eddy flux NEE measurements to the continental scale and produced spatially explicit estimates of NEE across multiple biomes.

Here we used remotely sensed data from the National Aeronautics and Space Administration's (NASA) Terra MODIS to scale eddy flux NEE measurements to the continental scale and produce wall-to-wall NEE estimates for the conterminous U.S. First, we developed a predictive NEE model based on site-specific MODIS and AmeriFlux data. Second, we validated the performance of the model with Ameriflux data. Third, we applied the model to estimate NEE for each $1 \mathrm{~km} \times 1 \mathrm{~km}$ cell across the conterminous U.S. for each 8-day period in 2005 using wall-to-wall MODIS data. Finally, we examined the spatiotemporal patterns of NEE across the conterminous U.S.

\section{Methods}

\subsection{Piecewise linear regression models}

A modified regression tree approach was used to scale towerbased NEE to the continental scale. Regression tree algorithms produce rule-based models containing one or more rules, each of which is a set of conditions associated with a linear submodel. Regression tree models allow both continuous and discrete variables as input variables, and account for a nonlinear relationship between predictive and target variables (Yang et al., 2003). These approaches are also proving not only more effective than simple techniques including multivariate linear regression, but also easier to understand than neural networks (Huang and Townshend, 2003). We used a modified regression tree algorithm implemented in the commercial software called Cubist. Cubist is a powerful tool for generating rule-based predictive models. A Cubist model resembles a piecewise linear model, except that the rules can overlap with one another (RuleQuest, 2008). Cubist has been used to estimate percent land cover (Huang and Townshend, 2003), impervious area (Yang et al., 2003), forest biomass (Salajanu and Jacobs, 2005), and ecosystem carbon fluxes (Wylie et al., 2007). Piecewise regression models were selected as the most appropriate approach for scaling the flux tower data to ecoregions (Wylie et al., 2007).

We chose Cubist to construct a predictive NEE model based on AmeriFlux NEE and satellite data. In Cubist, the predictive accuracy of a rule-based model can be improved by combining it with an instance-based/nearest-neighbor model that predicts the target value of a new case using the average predicted values of the $n$ most similar cases (RuleQuest, 2008). The use of the composite model can improve the predictive accuracy relative to the rule-based model alone. Cubist can also generate committee models made up of several rule-based models, and each member of the committee model predicts the target value for a case (RuleQuest, 2008). The member's predictions are averaged to give a final prediction.

Cubist uses three statistical measures to measure the quality of the constructed predictive model, including average error, relative error, and Pearson product-moment correlation coefficient. The average error $\left(E_{\mathrm{A}}\right)$ is calculated as (Yang et al., 2003):

$E_{\mathrm{A}}=\frac{1}{N} \sum_{i=1}^{N}\left|y_{i}-\hat{y}_{i}\right|$

where $N$ is the number of samples used to establish the predictive model, and $y_{i}$ and $\hat{y}_{i}$ are the actual and predicted values of the response variable, respectively. The relative error $\left(E_{R}\right)$ is calculated as (Yang et al., 2003):

$E_{\mathrm{R}}=\frac{E_{\mathrm{A}, \mathrm{T}}}{E_{\mathrm{A}, \mu}}$

where $E_{\mathrm{A}, \mathrm{T}}$ is the average error of the constructed model, and $E_{\mathrm{E}, \mu}$ is the average error that would result from always predicting the mean value. The Pearson product-moment correlation coefficient is a common measure of the correlation between two variables. All the three statistical measures provided by Cubist were used to evaluate the performance of the predictive model.

\subsection{Explanatory variables}

NEE is the difference between two carbon fluxes of photosynthesis and respiration (Law et al., 1999). It is influenced by a variety of physical, physiological, atmospheric, hydrologic, and edaphic variables. At the leaf level, photosynthesis or gross primary productivity (GPP) is influenced by several factors, including incoming solar radiation, air temperature, vapor pressure deficit, soil moisture, and nitrogen availability (Clark et al., 1999, 2004). At the ecosystem level, GPP is also influenced by leaf area index (LAI) and canopy phenology. Ecosystem respiration $\left(R_{\mathrm{e}}\right)$ includes autotrophic $\left(R_{\mathrm{a}}\right)$ and heterotrophic respiration $\left(R_{h}\right)$. Soil respiration is the largest 
Table 1 - Site descriptions including name, latitude, longitude, vegetation structure, years of data available, and references for each flux site in this study

\begin{tabular}{|c|c|c|c|c|c|c|c|}
\hline Site & State & Latitude & Longitude & Vegetation structure & Vegetation type & Year & References \\
\hline Audubon Research Ranch (ARR) & $\mathrm{AZ}$ & 31.59 & -110.51 & Desert grasslands & Grasslands & 2002-2006 & \\
\hline Santa Rita Mesquite (SRM) & $\mathrm{AZ}$ & 31.82 & -110.87 & Mesquite-dominated savanna & Savannas & 2004-2006 & Watts et al. (2007) \\
\hline Walnut Gulch Kendall Grasslands (WGK) & $\mathrm{AZ}$ & 31.74 & -109.94 & Warm season C4 grassland & Grasslands & 2004-2006 & \\
\hline Sky Oaks Old Stand (SOO) & CA & 33.37 & -116.62 & Chaparral (Mediterranean-type ecosystems) & Shrublands & 2004-2006 & Lipson et al. (2005) \\
\hline Sky Oaks Young stand (SOY) & $\mathrm{CA}$ & 33.38 & -116.62 & Chaparral (Mediterranean-type ecosystems) & Shrublands & 2001-2006 & Lipson et al. (2005) \\
\hline Tonzi Ranch (TR) & CA & 38.43 & -120.97 & $\begin{array}{l}\text { Oak savanna, grazed grassland dominated by } \\
\text { blue oak and grasses }\end{array}$ & Savannas & 2001-2006 & Ma et al. (2007) \\
\hline Vaira Ranch (VR) & CA & 38.41 & -120.95 & $\begin{array}{l}\text { Grazed C3 grassland opening in a region of } \\
\text { oak/grass savanna }\end{array}$ & Savannas & 2001-2006 & $\begin{array}{l}\mathrm{Xu} \text { and Baldocchi } \\
(2004)\end{array}$ \\
\hline Niwot Ridge Forest (NRF) & $\mathrm{CO}$ & 40.03 & -105.55 & $\begin{array}{l}\text { Subalpine coniferous forest dominated } \\
\text { by subalpine, Engelmann spruce, and } \\
\text { lodgepole pine }\end{array}$ & Evergreen forests & $2000-2003$ & Monson et al. (2002) \\
\hline Kennedy Space Center-Scrub Oak (KSC) & FL & 28.61 & -80.67 & $\begin{array}{l}\text { Scrub-oak palmetto dominated by } \\
\text { schlerophyllous evergreen oaks and the } \\
\text { Saw Palmetto Serenoa repens }\end{array}$ & Shrublands & 2000-2006 & Dore et al. (2003) \\
\hline Austin Cary-Slash Pine (AC) & FL & 29.74 & -82.22 & $\begin{array}{l}\text { Naturally regenerated pine dominated by } \\
\text { Pinus palustris/Pinus ellottii }\end{array}$ & Evergreen forests & $2001-2005$ & Powell et al. (2005) \\
\hline Bondville (Bon) & IL & 40.01 & -88.29 & Annual rotation between corn (C4) and soybeans (C3) & Croplands & 2001-2006 & Hollinger et al. (2005) \\
\hline FNAL Agricultural site (FAg) & IL & 41.86 & -88.22 & Soybean/corn & Croplands & 2005-2006 & \\
\hline FNAL Prairie site (FPr) & IL & 41.84 & -88.24 & Tall grass prairie & Grasslands & 2004-2006 & \\
\hline Morgan Monroe State Forest (MMS) & IN & 39.32 & -86.41 & $\begin{array}{l}\text { Mixed hardwood deciduous forest dominated } \\
\text { by sugar maple, tulip poplar, sassafras, white } \\
\text { oak, and black oak }\end{array}$ & Deciduous forests & 2000-2005 & Schmid et al. (2000) \\
\hline Harvard Forest EMS Tower (HFE) & MA & 42.54 & -72.17 & $\begin{array}{l}\text { Temperate deciduous forest dominated by red oak, } \\
\text { red maple, black birch, white pine, } \\
\text { and hemlock }\end{array}$ & Deciduous forests & 2000-2004 & Urbanski et al. (2007) \\
\hline Harvard Forest Hemlock (HFH) & MA & 42.54 & -72.18 & Temperate coniferous forest dominated by hemlock & Evergreen forests & 2004 & \\
\hline Little Prospect Hill (LPH) & MA & 42.54 & -72.18 & $\begin{array}{l}\text { Temperate deciduous forest dominated by red oak, } \\
\text { red maple, black birch, white pine, and hemlock }\end{array}$ & Deciduous forests & $2002-2005$ & \\
\hline Howland Forest (HF) & $\mathrm{ME}$ & 45.20 & -68.74 & $\begin{array}{l}\text { Boreal-northern hardwood transitional forest } \\
\text { consisting of hemlock-spruce-fir, aspen-birch, and } \\
\text { hemlock-hardwood mixtures }\end{array}$ & Evergreen forests & 2000-2004 & $\begin{array}{l}\text { Hollinger et al. } \\
(1999,2004)\end{array}$ \\
\hline Howland Forest West Tower (HFW) & ME & 45.21 & -68.75 & $\begin{array}{l}\text { Deciduous needle forest, Boreal/northern hardwood } \\
\text { ecoton, old coniferous }\end{array}$ & Deciduous forests & 2000-2004 & $\begin{array}{l}\text { Hollinger et al. } \\
(1999,2004)\end{array}$ \\
\hline Sylvania Wilderness Area (SWA) & MI & 46.24 & -89.35 & $\begin{array}{l}\text { Old-growth eastern hemlock/sugar maple/ } \\
\text { basswood/yellow birch }\end{array}$ & Mixed forests & 2002-2006 & Desai et al. (2005) \\
\hline Univ. of Mich. Biological Station (UMB) & MI & 45.56 & -84.71 & $\begin{array}{l}\text { Mid-aged conifer and deciduous, northern hardwood, } \\
\text { pine understory, aspen, mostly deciduous, } \\
\text { old-growth hemlock }\end{array}$ & Mixed forests & 2000-2003 & Gough et al. (2008) \\
\hline Missouri Ozark (MO) & MO & 38.74 & -92.20 & Oak hickory forest & Deciduous forests & 2004-2006 & Gu et al. $(2006,2007)$ \\
\hline Goodwin Creek (GC) & MS & 34.25 & -89.97 & Temperate grassland & Grasslands & 2002-2006 & \\
\hline Fort Peck (FPe) & MT & 48.31 & -105.10 & Grassland & Grasslands & 2000-2006 & \\
\hline Duke Forest Loblolly Pine (DFP) & NC & 35.98 & -79.09 & Even-aged loblolly pine forest & Evergreen forests & 2001-2005 & Oren et al. $(1998,2006)$ \\
\hline Duke Forest Hardwood (DFH) & NC & 35.97 & -79.10 & $\begin{array}{l}\text { An uneven-aged closed-canopy stand in an oak- } \\
\text { hickory type forest composed of mixed hardwood } \\
\text { species with pine (Pinus taeda) as a minor component }\end{array}$ & Deciduous forests & $2003-2005$ & Pataki and Oren (2003) \\
\hline
\end{tabular}




\begin{tabular}{|c|c|c|c|c|c|c|c|}
\hline North Carolina Loblolly Pine (NCP) & NC & 35.80 & -76.67 & 15-Year-old loblolly pine (Pinus taeda) plantation & Evergreen forests & 2005-2006 & $\begin{array}{l}\text { Noormets et al. } \\
\text { (unpublished) }\end{array}$ \\
\hline Mead Irrigated Continuous (MIC) & $\mathrm{NE}$ & 41.17 & -96.48 & Continuous maize & Croplands & 2001-2005 & Verma et al. (2005) \\
\hline Mead Irrigated Rotation (MIR) & NE & 41.16 & -96.47 & Maize-soybean rotation & Croplands & 2001-2005 & Verma et al. (2005) \\
\hline Mead Rainfed (MR) & NE & 41.18 & -96.44 & Maize-soybean rotation & Croplands & 2001-2005 & Verma et al. (2005) \\
\hline Bartlett Experimental Forest (BEF) & $\mathrm{NH}$ & 44.06 & -71.29 & $\begin{array}{l}\text { Temperate northern hardwood forest dominated } \\
\text { by American beech, red maple, paper birch, } \\
\text { and hemlock }\end{array}$ & Deciduous forests & 2004-2005 & Jenkins et al. (2007) \\
\hline Toledo Oak Openings (TOP) & $\mathrm{OH}$ & 41.33 & -83.51 & $\begin{array}{l}\text { Oak Savannah dominated by Quercus rubra, } \\
\text { Quercus alba, and Acer rubrum }\end{array}$ & Savannas & 2004-2005 & Noormets et al. (2008b) \\
\hline ARM Oklahoma (ARM) & $\mathrm{OK}$ & 36.61 & -97.49 & Winter wheat, some pasture and summer crops & Croplands & 2003-2006 & \\
\hline Metolius Intermediate (MI) & OR & 44.45 & -121.56 & $\begin{array}{l}\text { Intermediate-aged temperate coniferous forest } \\
\text { dominated by Pinus ponderosa, Purshia tridentate, } \\
\text { Arctostaphylos patula }\end{array}$ & Evergreen forests & 2003-2005 & $\begin{array}{l}\text { Law et al. (2003) } \\
\text { and Irvine et al. (2007) }\end{array}$ \\
\hline Metolius New (MN) & OR & 44.32 & -121.61 & $\begin{array}{l}\text { Young temperate coniferous forest dominated } \\
\text { by Pinus ponderosa and Purshia tridentata }\end{array}$ & Evergreen forests & 2004-2005 & $\begin{array}{l}\text { Law et al. (2003) } \\
\text { and Irvine et al. (2007) }\end{array}$ \\
\hline Brookings (Bro) & SD & 44.35 & -96.84 & Temperate grassland & Grasslands & 2004-2006 & \\
\hline Freeman Ranch Mesquite Juniper (FRM) & TX & 29.95 & -98.00 & $\begin{array}{l}\text { Grassland in transition to an Ashe juniper- } \\
\text { dominated woodland }\end{array}$ & Savannas & 2004-2006 & \\
\hline Wind River Crane Site (WRC) & WA & 45.82 & -121.95 & $\begin{array}{l}\text { Temperate coniferous forest dominated by } \\
\text { Douglas-fir and western hemlock }\end{array}$ & Evergreen forests & 2000-2004 & Falk et al. (2008) \\
\hline Lost Creek (LC) & WI & 46.08 & -89.98 & Alder-willow deciduous wetland & Deciduous forests & 2000-2005 & \\
\hline Willow Creek (WC) & WI & 45.81 & -90.08 & $\begin{array}{l}\text { Temperate/Boreal forest dominated by white ash, } \\
\text { sugar maple, basswood, green ask, and red oak }\end{array}$ & Deciduous forests & 2000-2006 & Cook et al. (2004) \\
\hline Wisconsin intermediate hardwood (WIH) & WI & 46.73 & -91.23 & $\begin{array}{l}\text { 17-Year-old regeneration mixed northern } \\
\text { hardwood with bigtooth aspen (Populus } \\
\text { grandidentata) dominance }\end{array}$ & Deciduous forests & 2003 & Noormets et al. (2008a) \\
\hline Mature Red Pine (MRP) & WI & 46.74 & -91.17 & 65-Year-old red pine (Pinus resinosa) plantation & Evergreen forests & 2002-2005 & Noormets et al. (2007) \\
\hline
\end{tabular}


component of ecosystem respiration. Because autotrophic and heterotrophic activity belowground is controlled by rooting systems and substrate availability, soil respiration is strongly linked to plant metabolism, photosynthesis and litterfall (Ryan and Law, 2005). $R_{a}$ can be empirically modeled as a function of air temperature and tissue carbon (foliage, stem, and roots), whereas $R_{h}$ is often modeled as a function of substrate availability, soil temperature and soil moisture (Ryan and Law, 2005). At the stand or regional level, NEE is significantly affected by disturbances from fire and harvest (Thornton et al., 2002; Law et al., 2004) and fractional vegetation cover (DeFries et al., 2002).

Many of these factors influencing NEE can be assessed by satellite remote sensing. Optical remote sensing systems measure the surface reflectance, the fraction of solar energy that is reflected by the Earth's surface. For a given wavelength, different vegetation types and/or plant species may have different reflectance (Schmidt and Skidmore, 2003). The reflectance of the same vegetation type also depends on wavelength region, biophysical properties (e.g., biomass, leaf area, and stand age), soil moisture, and sun-object-sensor geometry (Ranson et al., 1985; Penuelas et al., 1993). Therefore, reflectance values from multiple spectral bands can provide useful information for estimating NEE. Moreover, surface reflectance can be used to develop vegetation indices and biophysical parameters that can account for factors influencing NEE, such as the normalized difference vegetation index (NDVI), the enhanced vegetation index (EVI), the land surface temperature (LST), the normalized difference water index (NDWI), the fraction of photosynthetically active radiation absorbed by vegetation canopies (PAR), and LAI.

The NDVI captures the contrast between the visible-red and near-infrared reflectance of vegetation canopies. It is defined as

$\mathrm{NDVI}=\frac{\rho_{\text {nir }}-\rho_{\text {red }}}{\rho_{\text {nir }}+\rho_{\text {red }}}$

where $\rho_{\text {red }}$ and $\rho_{\text {nir }}$ are the visible-red and near-infrared reflectance, respectively. NDVI is closely correlated to the fraction of photosynthetically active radiation (fPAR) absorbed by vegetation canopies (Asrar et al., 1984; Law and Waring, 1994) and photosynthetic activity (Xiao and Moody, 2004). NDVI is also related to vegetation biomass (Myneni et al., 2001) and fractional vegetation cover (Xiao and Moody, 2005). However, NDVI has several limitations, including saturation in a multilayer closed canopy and sensitivity to both atmospheric aerosols and soil background (Huete et al., 2002; Xiao and Moody, 2005). To account for these limitations of NDVI, Huete et al. (1997) developed the improved vegetation index, EVI:

$\mathrm{EVI}=2.5 \frac{\rho_{\text {nir }}-\rho_{\text {red }}}{\rho_{\text {nir }}+\left(6 \rho_{\text {red }}-7.5 \rho_{\text {blue }}\right)+1}$

where $\rho_{\text {nir }}, \rho_{\text {red }}$, and $\rho_{\text {blue }}$ are the spectral reflectance at the near-infrared, red, and blue wavelengths, respectively. Huete et al. (2002) has developed a global EVI product from MODIS data for the period from 2000 to present.

The LST derived from MODIS is a measure of the soil temperature at the surface. The MODIS LST agreed with in situ measured LST within $1 \mathrm{~K}$ in the range 263-322 $\mathrm{K}$ (Wan et al.,
2002). LST is likely a good indicator of $R_{e}$ as both $R_{a}$ and $R_{H}$ are significantly affected by air/surface temperature. Rahman et al. (2005) demonstrated that satellite-derived LST was strongly correlated with $R_{\mathrm{e}}$.

As the shortwave infrared (SWIR) spectral band is sensitive to vegetation water content and soil moisture, a combination of NIR and SWIR bands have been used to derive watersensitive vegetation indices (Ceccato et al., 2002). Gao (1996) developed the NDWI from satellite data to measure vegetation liquid water:

$\mathrm{NDWI}=\frac{\rho_{\text {nir }}-\rho_{\text {swir }}}{\rho_{\text {nir }}+\rho_{\text {swir }}}$

where $\rho_{\text {swir }}$ is the reflectance at the SWIR spectral band. The NDWI was shown to be strongly correlated with leaf water content (equivalent water thickness (EWT), $\mathrm{g} \mathrm{H}_{2} \mathrm{O} \mathrm{m}{ }^{-2}$ ) (Jackson et al., 2004) and soil moisture (Fensholt and Sandholt, 2003) over time. It was incorporated into the vegetation photosynthesis model (VPM) as a water scalar for estimating GPP (Xiao et al., 2005). Yet, there is still a question as to whether NDWI provides useful information on canopy water stress status that affects photosynthesis because of its sensitivity to the relatively small changes in relative water content observed in natural vegetation, and inability to discern changes in canopy biomass from changes in canopy moisture status (Hunt and Rock, 1989; Gao, 1996).

Satellite data can also provide estimates for LAI and PPAR. These two variables characterize vegetation canopy functioning and energy absorption capacity (Myneni et al., 2002), and are key parameters in most ecosystem productivity and biogeochemical models due to their high correlation with GPP (Sellers et al., 1997).

We therefore selected surface reflectance, EVI, LST, NDWI, fPAR, and LAI as explanatory variables. All these variables were derived from MODIS data, which also avoided the complications and difficulties to merge disparate data sources.

\subsection{Data}

We obtained the following three types of data: NEE from eddy covariance flux towers, explanatory variables derived from MODIS, and a land cover map derived from MODIS.

\subsubsection{Ameriflux data}

The Ameriflux network coordinates regional analysis of observations from eddy covariance flux towers across North America, Central America, and South America (Law, 2006). We obtained the Level 4 NEE product for 42 AmeriFlux sites for the period 2000-2006 from the AmeriFlux website (http://public.ornl.gov/ameriflux/) (Table 1). These sites are distributed across the conterminous U.S. (Fig. 1), and cover a range of vegetation types including forests, shrublands, savannas, grasslands, and croplands (Table 1). Moreover, the distribution of these sites in the mean annual climate space (Fig. 2) indicates that they cover typical U.S. climate types. In addition, they also include some forest sites at different times since stand replacing disturbance, which are located in disturbance clusters of sites. We therefore believe that these sites are fairly representative of U.S. ecosystem and climate types. 


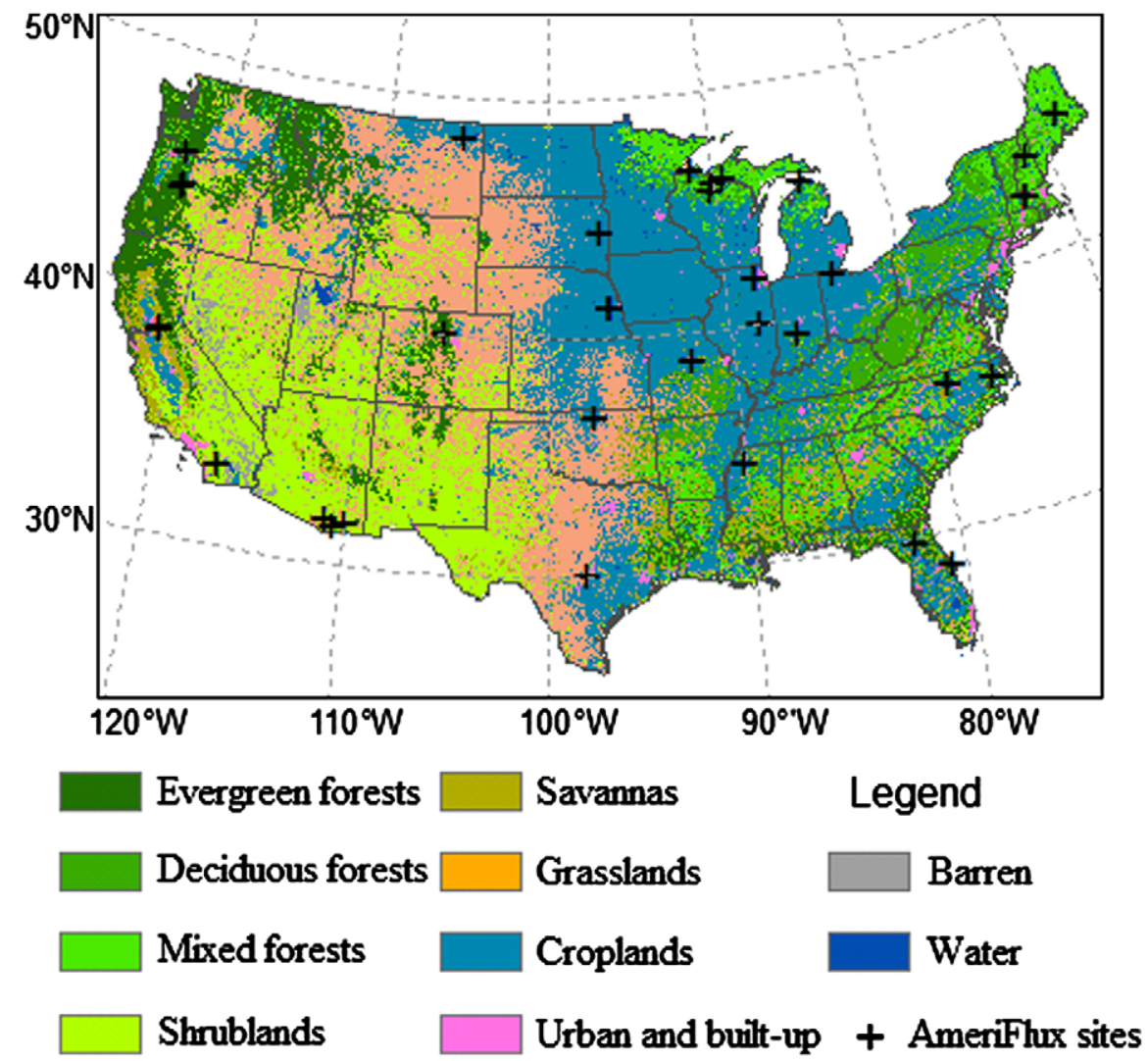

Fig. 1 - Location and spatial distribution of the Ameriflux sites used in this study. The base map is the reclassified MODIS land-cover map that was used for the continental-scale estimation of NEE. Symbols indicate the location of the AmeriFlux sites.

The Level 4 product consists of two types of NEE data, including standardized (NEE_st) and original (NEE_or) NEE (AmeriFlux, 2007). NEE_st was calculated using $\mathrm{CO}_{2}$ flux estimated by the eddy covariance method, which includes summation with $\mathrm{CO}_{2}$ storage in the canopy air space that was obtained from the discrete approach (single point on the top of the tower) for all the sites, whereas NEE_or was calculated using the storage obtained from within canopy $\mathrm{CO}_{2}$ profile measurements in relatively tall forest canopies or from the discrete approach. The average data coverage during a year is only $65 \%$ due to system failures or data rejection, and therefore robust and consistent gap filling methods are required to provide complete data sets (Falge et al., 2001). Both NEE_st and NEE_or were filled using the Marginal Distribution Sampling (MDS) method (Reichstein et al., 2005) and the Artificial Neural Network (ANN) method (Papale and Valentini, 2003). The ANN method was generally, if only slightly, superior to the MDS method (Moffat et al., 2007). Therefore, we used the gap-filled NEE data based on the ANN method. For each site, if the percentage of the remaining missing values for NEE_st was lower than that for NEE_or, we selected NEE_or; otherwise, we used NEE_st. In this product, negative sign denotes carbon uptake, and positive sign denotes carbon release.

The Level 4 product consists of NEE data with four different time steps, including half-hourly, daily, weekly (8-day), and monthly. We used 8-day NEE data $\left(\mathrm{gC} \mathrm{m}^{-2}\right.$ day $\left.^{-1}\right)$ to match the compositing intervals of MODIS data. Moreover, the average NEE over such a period was shown to largely eliminate micrometeorological sampling errors, with the remaining spatial variability representing variation in ecosystem attributes (Oren et al., 2006), here accounted for by data from MODIS.

\subsubsection{MODIS data}

MODIS is a key instrument on board the NASA's Terra and Aqua satellites. The Terra MODIS and Aqua MODIS view the entire Earth's surface every 1-2 days, acquiring data in 36 spectral bands and with the spatial resolution of $250 \mathrm{~m}, 500 \mathrm{~m}$, and $1 \mathrm{~km}$. We used the following four MODIS data products: surface reflectance (MOD09A1; Vermote and Vermeulen, 1999), daytime and nighttime LST (MOD11A2; Wan et al., 2002), EVI (MOD13A1; Huete et al., 2002), and LAI/fPAR (MOD15A2; Myneni et al., 2002). Surface reflectance data consist of reflectance values of seven spectral bands: blue $(459-479 \mathrm{~nm})$, green $(545-565 \mathrm{~nm})$, red $(620-670 \mathrm{~nm})$, nearinfrared (841-875 $\mathrm{nm}$ and $1230-1250 \mathrm{~nm})$, and shortwave infrared (1628-1652 nm and 2105-2155 nm). Surface reflectance and EVI are at a spatial resolution of $500 \mathrm{~m}$, while LAI, fPAR, and LAI are at spatial resolution of $1 \mathrm{~km}$. Surface reflectance, fPAR, and LAI are at a temporal resolution of 8 days, while EVI is at a temporal resolution of 16 days. 


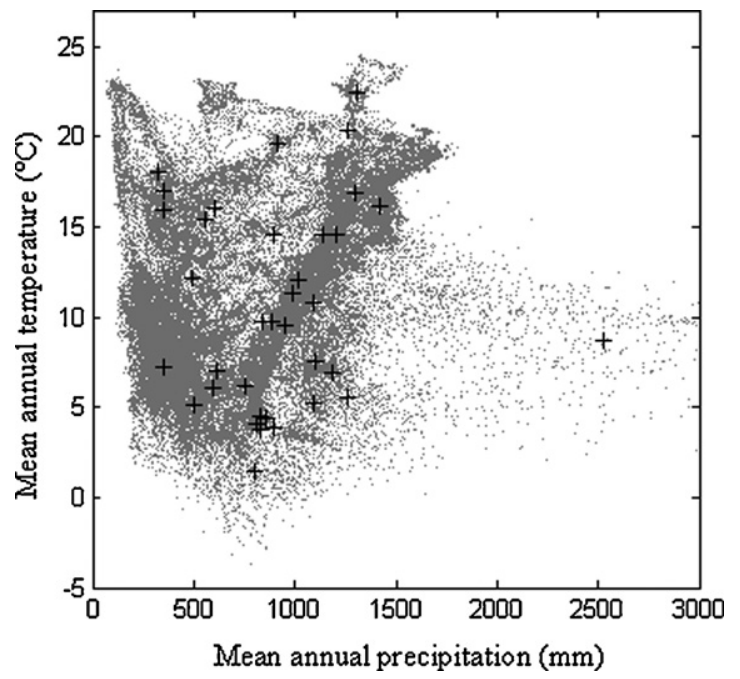

Fig. 2 - Distribution of the 42 Ameriflux sites in mean annual climate space. Climate parameters are the mean annual precipitation ( $x$-axis) and mean annual temperature ( $y$-axis) taken over a 30-year period of record (1971-2000) from the PRISM database (http:// www.prism.oregonstate.edu/). Gray points indicate the climate space distribution of landmass within the conterminous United States. The climate data have been resampled to $12 \mathrm{~km}$ resolution for plotting points in this figure. Symbols show the location of each Ameriflux site in the climate space. The climate data of the sites are from the Ameriflux website (http://public.ornl.gov/ameriflux/) and the PRISM database.

For each AmeriFlux site, we obtained the MODIS ASCII (American Standard Code for Information Interchange) subsets (Collection 4) consisting of $7 \mathrm{~km} \times 7 \mathrm{~km}$ regions centered on the flux tower from the Oak Ridge National Laboratory's Distributed Active Archive Center (ORNL DAAC, 2006). We extracted average values for the central $3 \mathrm{~km} \times 3 \mathrm{~km}$ area within the $7 \mathrm{~km} \times 7 \mathrm{~km}$ cutouts to better represent the flux tower footprint (Schmid, 2002; Rahman et al., 2005). For each variable, we determined the quality of the value of each pixel within the area using the quality assurance (QA) flags included in the product. At each time step, we averaged the values of each variable using the pixels with good quality within the area to represent the values at the flux site. If none of the values within the $3 \mathrm{~km} \times 3 \mathrm{~km}$ area was of good quality, we treated the period as missing. Each 16-day EVI value was split into two 8-day values to correspond with the compositing interval of other MODIS data products.

For the continental-scale estimation of NEE, we obtained continental-scale MODIS data including surface reflectance, daytime and nighttime LST, and EVI from the Earth Observing System (EOS) Data Gateway (http://edcimswww.cr.usgs.gov/ pub/imswelcome/). For each variable and for each 8- or 16-day period, a total of 22 tiles were needed to cover the conterminous U.S., and these tiles were mosaiced to generate a continental-scale image. For each variable, we determined the quality of the value of each pixel using the QA flags, and replaced the bad value using a linear interpolation approach (Zhao et al., 2005). The NDWI was calculated from band 2 (near-infrared) and band 6 (shortwave infrared) of the surface reflectance product according to Eq. (5).

\subsubsection{Land cover}

To construct the predictive NEE model, we obtained the land cover type for each Ameriflux site based on the site descriptions (Table 1), and categorized each site into a class of the University of Maryland land-cover classification system (UMD). Although the 42 Ameriflux sites used in this study cover a variety of vegetation classes of this classification system, some classes (e.g., deciduous needleleaf forests and open shrublands) were not covered by any site. We therefore reclassified all vegetation classes of the UMD classification system to seven broader classes (Table 2). Specifically, evergreen needleleaf forests and evergreen broadleaf forests were merged to evergreen forests, deciduous needleleaf forests and deciduous broadleaf forests to deciduous forests, closed shrublands and open shrublands to shrublands, and woody savannas and savannas to savannas.

To estimate NEE for each $1 \mathrm{~km} \times 1 \mathrm{~km}$ cell at the continental scale, we obtained the land cover type for each cell from the MODIS land cover map with the UMD classification system (Friedl et al., 2002). Similarly, we reclassified the vegetation types of the MODIS land cover map to the seven broader classes (Table 2). The reclassified land-cover map is shown in Fig. 1.

\begin{tabular}{|c|c|c|}
\hline Vegetation types & UMD classes & Definition (Belward and Loveland, 1996) \\
\hline Evergreen forests & $\begin{array}{l}\text { Evergreen needleleaf forests (1) } \\
\text { and evergreen broadleaf forests ( } 2 \text { ) }\end{array}$ & $\begin{array}{l}\text { Tree canopy cover }>60 \% \text { and tree height }>2 \mathrm{~m} \text {. Most of } \\
\text { the canopy remains green all year }\end{array}$ \\
\hline Deciduous forests & $\begin{array}{l}\text { Deciduous needleleaf forests (3) } \\
\text { and deciduous broadleaf forests ( } 4 \text { ) }\end{array}$ & $\begin{array}{l}\text { Tree canopy cover }>60 \% \text { and tree height }>2 \mathrm{~m} \text {. Most of } \\
\text { the canopy is deciduous }\end{array}$ \\
\hline Mixed forests & Mixed forests (5) & $\begin{array}{l}\text { Tree canopy cover }>60 \% \text { and tree height }>2 \mathrm{~m} \text {. Mixed } \\
\text { evergreen and deciduous canopy }\end{array}$ \\
\hline Shrublands & Closed shrublands (6) and open shrublands (7) & $\begin{array}{l}\text { Shrub canopy cover }>10 \% \text { (10-60\% for open shrublands, }>60 \% \\
\text { for closed shrublands) and height }<2 \mathrm{~m}\end{array}$ \\
\hline Savannas & Woody savannas (8) and savannas (9) & $\begin{array}{l}\text { Forest canopy cover between } 10-60 \% \text { (30-60\% for woody } \\
\text { savannas, } 10-30 \% \text { for savannas) and height }>2 \mathrm{~m}\end{array}$ \\
\hline Grasslands & Grasslands (10) & Herbaceous cover. Woody cover $<10 \%$ \\
\hline Croplands & Croplands (12) & Temporary crops followed by harvest and a bare soil period \\
\hline
\end{tabular}




\subsection{Model development}

We developed a predictive NEE model using Cubist based on the site-specific MODIS and AmeriFlux NEE data. Our explanatory variables included surface reflectance (7 bands), daytime and nighttime LST, EVI, fPAR, and LAI, and our target variable was NEE. We split the site level data set of AmeriFlux and MODIS data into a training set (2000-2004) and a test set (2005-2006). If a site only had NEE observations for the period 2000-2004, the site was only included in the training set; if a site only had NEE observations for the period 2005-2006, the site was only included in the test set; otherwise, the site was included in both training and test sets. The training and test sets included 40 and 34 AmeriFlux sites, respectively. Each set included sites at different stages since stand-replacing disturbances. Altogether we had a total of 4596 and 2257 data points for the training and test sets, respectively. We trained the model with the training set, and tested the model with the test set. In addition to the full model that includes all the 14 explanatory variables, we also developed a series of models by dropping one or more variables at a time using Cubist. To select the best model, we evaluated the performance of each model based on the average error, relative error, and correlation coefficient. We chose the model with the minimal average error and relative error and maximum correlation coefficient as the best model. We also evaluated model performance using scatterplots of predicted versus observed NEE and seasonal variations between the predicted and observed NEE.

\subsection{Continental-scale estimation of NEE}

As mentioned earlier, the AmeriFlux sites we selected are fairly representative of the U.S. ecosystem and climate types. We believe that the predictive NEE model constructed from the 42 sites can be extrapolated to the conterminous U.S. Thus, we applied the predictive NEE model to estimate NEE for each $1 \mathrm{~km} \times 1 \mathrm{~km}$ cell across the conterminous U.S. for each 8-day period in 2005 using wall-to-wall MODIS data. We then examined the spatiotemporal patterns of our NEE estimates.

\section{Results and discussion}

\subsection{Model development}

The best model contained the following explanatory variables: surface reflectance bands 1-6, EVI, daytime and nighttime LST, and NDWI (relative error $=0.64$, average error $=0.986, r=0.73$ ). This model achieved slightly higher performance than the full model (relative error $=0.66$, average error $=1.01, r=0.72$ ). The selected model consisted of five committee models, each of which was made of a number of rule-based submodels. For example, the first committee model was made of 26 rule-based submodels:

Rule 1: if land cover $=$ croplands, daytime LST $>30.07$, EVI $>0.40$, then

$$
\begin{aligned}
\mathrm{NEE}= & 20.24-430.3 \mathrm{~B}_{3}+431.7 \mathrm{~B}_{4}+80.8 \mathrm{~B}_{1}-108.7 \mathrm{~B}_{5} \\
& -23.4 \mathrm{EVI}+0.22 \mathrm{~L}_{\mathrm{d}}+11.4 \mathrm{NDWI}-27.6 \mathrm{~B}_{6}+4 \mathrm{~B}_{2}
\end{aligned}
$$

Rule 2: if land cover in \{deciduous forests, savannas\}, $B_{2}>0.34$, NDWI $<=-0.36, L_{d}>18.06, L_{n}>11.13$, then

$$
\begin{aligned}
\mathrm{NEE}= & -5.94+47.2 \mathrm{~B}_{4}-35 \mathrm{~B}_{1}-12.7 \mathrm{~B}_{2}-7 \mathrm{~B}_{3}-3.6 \mathrm{NDWI} \\
& +8.4 \mathrm{~B}_{6}+4.4 \mathrm{~B}_{5}-0.4 \mathrm{EVI}
\end{aligned}
$$

Rule 25: if land cover in \{deciduous forests, mixed forests, croplands\}, NDWI $>0.02, L_{\mathrm{n}}<=9.68$, then

$$
\begin{aligned}
\mathrm{NEE}= & 0.40-37.6 \mathrm{~B}_{4}+15.1 B_{1}+8.9 B_{2}+0.046 L_{n}+0.9 B_{5} \\
& +0.4 B_{3}
\end{aligned}
$$

Rule 26: if land cover in \{deciduous forests, mixed forests, croplands $\}$, NDWI $>0.02, L_{n}>9.68$, then

$$
\begin{aligned}
\mathrm{NEE}= & -2.86+56.5 \mathrm{~B}_{5}-50.5 \mathrm{~B}_{6}+14.9 \mathrm{NDWI}-2.9 \mathrm{~B}_{1}-0.5 \mathrm{~B}_{4} \\
& -0.5 \mathrm{~B}_{2}
\end{aligned}
$$

where $B_{1}-B_{6}$ are surface reflectance bands $1-6, L_{d}$ is daytime LST, and $L_{n}$ is nighttime LST. The model estimated NEE reasonably well ( $r=0.73, p<0.001$; Fig. 3 ) considering that we used multiple years of data from a number of sites involving a variety of vegetation types across the conterminous U.S. The model slightly underestimated positive NEE values, and overestimated negative NEE values, where negative values indicate carbon uptake, and positive values indicate carbon release. In absolute magnitude, the model slightly underestimated both carbon release and uptake rates, thus damping the observed amplitude.

The analysis of NEE residuals (Fig. 4) indicated that the residuals were not randomly distributed. In absolute magnitude, low NEE values were generally associated with low prediction errors, whereas high NEE values were associated with high prediction errors. This suggests that the uncertainties of carbon flux measurements are directly proportional to the magnitude of the fluxes (Richardson et al., 2008). In

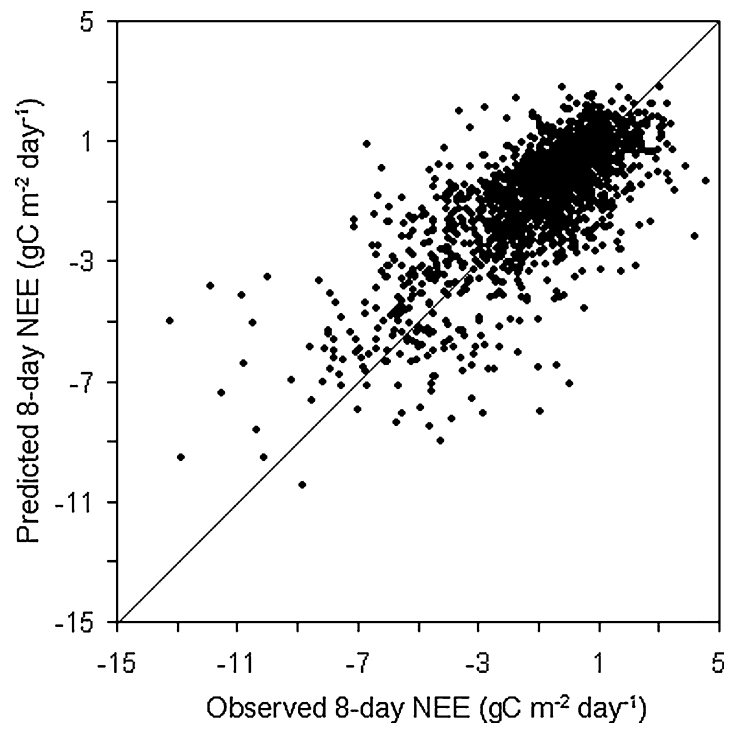

Fig. 3 - Scatterplot of observed 8-day NEE versus predicted 8-day NEE. The solid line is the 1:1 line. 


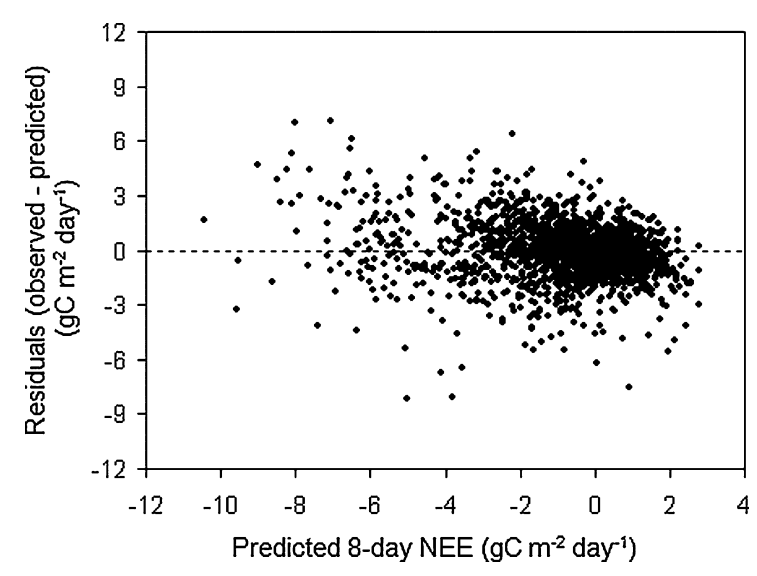

Fig. 4 - Scatterplot of predicted 8-day NEE versus residuals (observed - predicted) over the period 2005-2006.

addition, the explanatory variables included in the model could not completely explain the variance of NEE. For example, the independent variables used in the model could not account for the sizes of soil organic carbon pools, thereby affecting the performance of the model for estimating NEE.

We calculated the average error and relative error across all AmeriFlux sites for each 8-day period, and then plotted these two types of error against time (Fig. 5). The average error showed a strong seasonality. In absolute magnitude, winter had low average errors $\left(\sim 0.6 \mathrm{gC} \mathrm{m}^{-2} \mathrm{day}^{-1}\right)$, whereas warm season errors often exceeded $1 \mathrm{gC} \mathrm{m}^{-2}$ day $^{-1}$. This was not surprising as in absolute magnitude, winter months generally had relatively low NEE, while summer months had relatively high NEE. Unlike the average error, the relative error did not exhibit a strong seasonality, indicating that the model performance did not substantially vary with season.

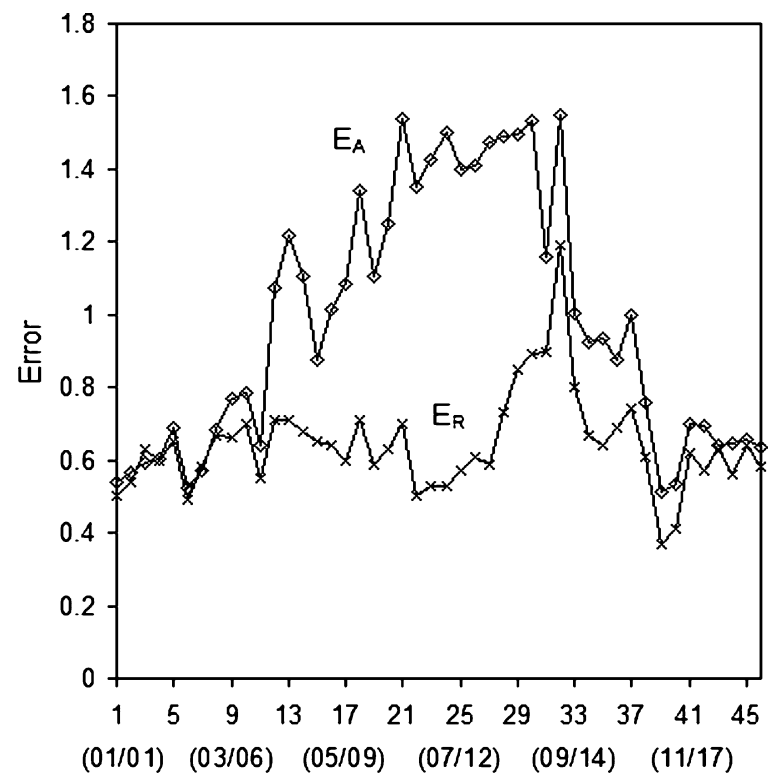

8-day interval

Fig. 5 - The average error $\left(E_{A}\right)$ and relative error $\left(E_{R}\right)$ averaged across all Ameriflux sites and over the period 2005-2006 for each 8-day period.
We also compared our NEE estimates with observed NEE for each AmeriFlux site (Fig. 6). The NEE estimates captured most features of observed NEE such as seasonality and interannual variability over the period 2005-2006. For some sites, episodes of under- or over-prediction occurred. The model could not capture exceptionally high and low NEE values that represented large carbon release and uptake rates, respectively for some sites, such as Audubon Research Ranch (AZ), FNAL (Fermi National Accelerator Laboratory) Agricultural site (IL), Goodwin Creek (MS), and Fort Peck (MT). In absolute magnitude, the model substantially underestimated those exceptional values. For example, the model estimates were far below the observed NEE values that were greater than $2 \mathrm{gC} \mathrm{m}^{-2} \mathrm{day}^{-1}$ at the Goodwin Creek site (MS), and were far greater than the observed NEE values that were below $-3 \mathrm{gC} \mathrm{m}^{-2}$ day $^{-1}$ at the Audubon Research Ranch site (AZ). Overall, the model performed better for deciduous forests, savannas, grasslands and croplands than for evergreen forests and shrublands.

The disagreement between estimated and observed NEE values is likely due to the following reasons. First, the MODIS and tower footprints do not always match with each other. As mentioned earlier, for each explanatory variable derived from MODIS data, we used the values averaged within the $3 \mathrm{~km} \times 3 \mathrm{~km}$ area (i.e., MODIS footprint) surrounding each flux tower to represent the values of the tower site. For most sites, vegetation structure within the $3 \mathrm{~km} \times 3 \mathrm{~km}$ area surrounding the flux tower is similar to that at the tower, and therefore the MODIS footprint may match with the tower footprint. However, some sites are located in complex land mosaics, and the vegetation structure at the flux tower could be significantly different from that within the MODIS footprint. For example, the Tonzi Ranch site (CA) is dominated by deciduous blue oaks (Quercus douglasii), and the understory and open grassland are dominated by cool-season $C_{3}$ annual species (Ma et al., 2007). The MODIS footprint, however, consists of a larger fraction of grassland. The phenologies of blue oaks and grassland are distinct from each other (Ma et al., 2007), and therefore these two plant species had differential contributions to the NEE integrated over the MODIS footprint. In the spring, wet conditions along with warm temperatures facilitated the fast growth of grass, leading to large carbon uptake rates within the MODIS footprint. As a result, in absolute magnitude, our NEE estimates were higher than the observed values at the tower site. Grasses senesced by the end of the spring as the rainy season ended (Ma et al., 2007). The senescence of grasses led to carbon release in the summer, and thus lowered the carbon uptake rates integrated over the MODIS footprint. Therefore, in absolute magnitude, our NEE values were much lower than the observed values at the tower in the summer.

Second, some sites experienced substantial disturbances that alter ecosystem carbon fluxes. For example, the Austin Cary site (FL) suffered from an extreme drought over the period 1999-2002; a prescribed burn at the site in 2003 then removed $95 \%$ of the understory vegetation; the site was also hit by three hurricanes in 2004 . These disturbances reduced carbon uptake rates, whereas MODIS data are less sensitive to changes in understory vegetation in forest ecosystems, thereby leading to substantial overestimation of carbon uptake rates. 
Third, our model could not sufficiently account for the factors influencing $R_{H}$. As mentioned earlier, $R_{H}$ is influenced by substrate availability, soil temperature, and soil moisture. LST and NDWI can account for soil temperature and soil moisture. However, surface reflectance can only partly account for non-photosynthetic material (e.g., litter). Root and associated mycorrhizal respiration produce roughly half
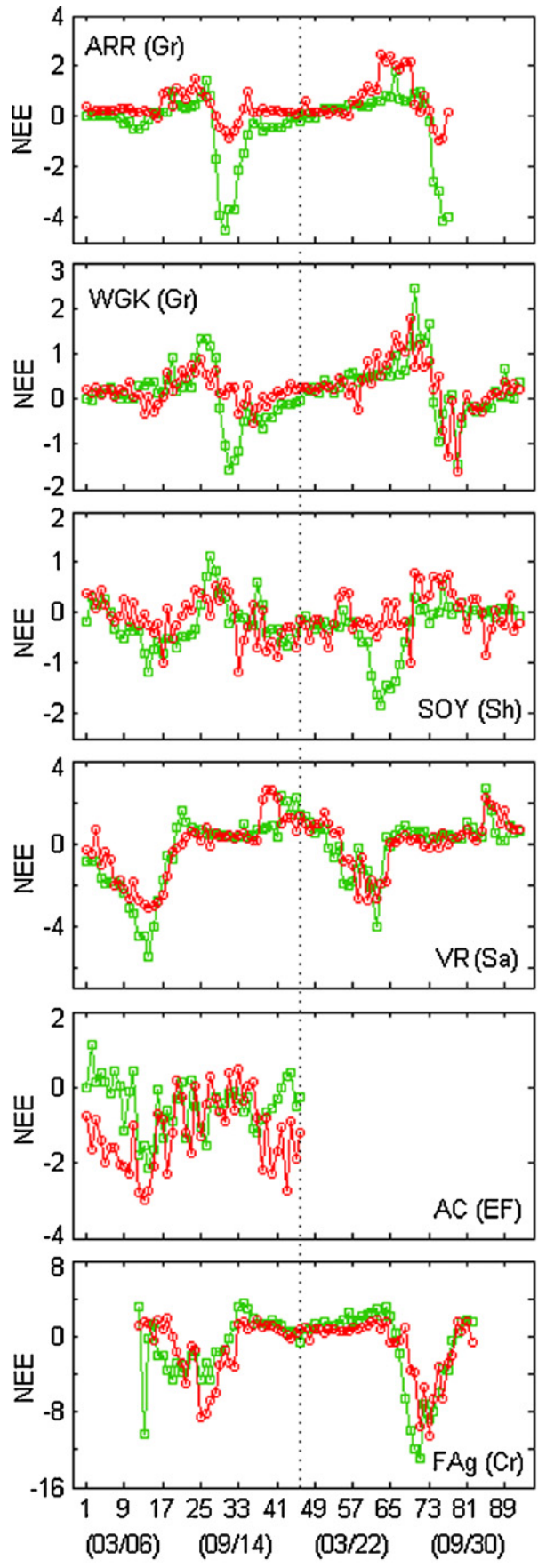

8-day interval of soil respiration, with much of the remainder derived from decomposition of recently produced root and leaf litter (Ryan and Law, 2005). Changes in the carbon stored in the soil generally contribute little to soil respiration, but these changes, together with shifts in plant carbon allocation, determine ecosystem carbon storage belowground and its exchange with the atmosphere (Ryan and Law, 2005). The
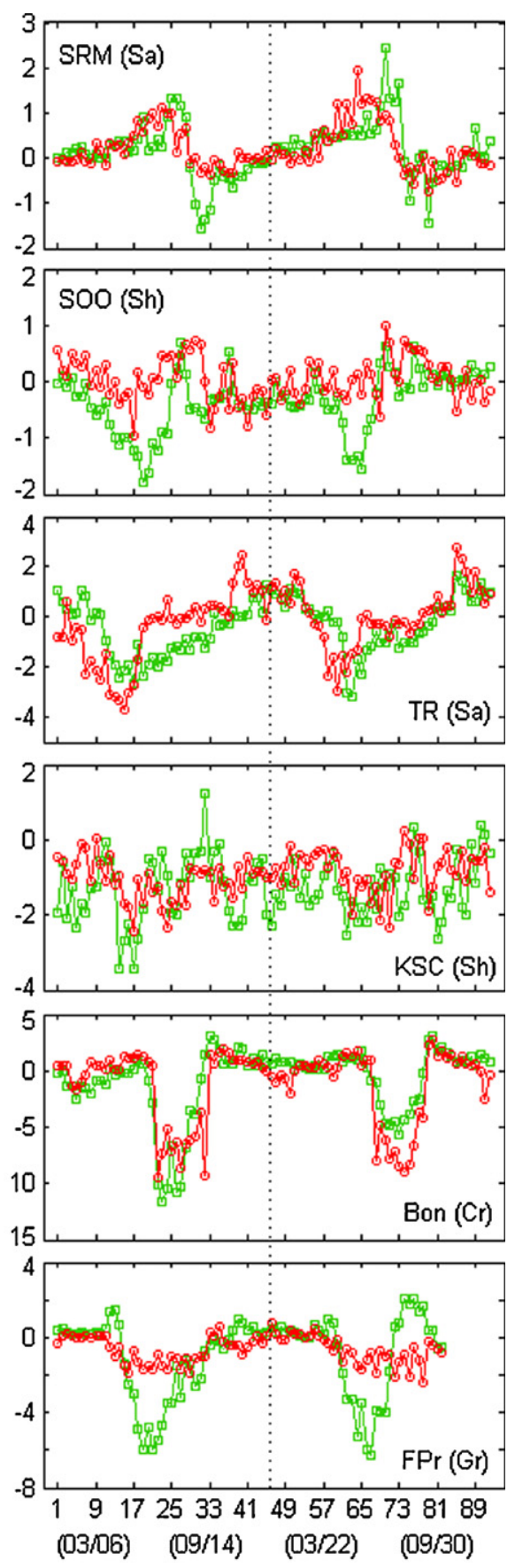

8-day interval

Fig. 6 - Observed and predicted 8-day NEE $\left(\mathrm{gC} \mathrm{m}^{-2}\right.$ day $\left.^{-1}\right)$ for each AmeriFlux site over the period 2005-2006. The green line with square symbols represents the observed values, and the red line with circle symbols represents the predicted values. For $x$-axis, the starting dates (month/day) of every two 8-day intervals were given in parentheses under interval numbers. Dashed lines were used to separate 2005 from 2006. Site abbreviations are used here, and their full names are given in Table 1. The vegetation type for each site is given in parenthesis: evergreen forests (EF), deciduous forests (DF), mixed forests (MF), shrublands (Sh), savannas (Sa), grasslands (Gr), and croplands (Cr). 
inability of our model to account for transient carbon pools contributed to the uncertainties in the NEE estimates (Richardson et al., 2007).

Finally, we estimated NEE for 8-day intervals, and therefore our estimates could not capture the variability of NEE within the intervals. The MODIS LST and EVI products were averaged from the corresponding daily products over a period of 8 and 16 days, respectively (Huete et al., 2002; Wan et al., 2002). For each period, only data with good quality were retained for compositing, and thus the number of days actually used for compositing is often lower than the total number of days over the period. The compositing technique for the MODIS surface reflectance product is based on the minimum-blue criterion that selects the clearest conditions over the 8-day period (Vermote and Vermeulen, 1999). Therefore, the 8- or 16-day values do not always represent the average environmental conditions and average fluxes over the 8- or 16-day period. For example, each 16-day EVI composite was an average of daily EVI over a period of 16 days. The number of acceptable pixels over a 16-day compositing period is typically less than 10 (often less than 5) due to cloud contaminations and extreme off-nadir sensor view angles (Huete et al., 2002). Sims et al. (2005) suggested that midday GPP derived from daily satellite snapshots of vegetation was highly correlated with 8-day
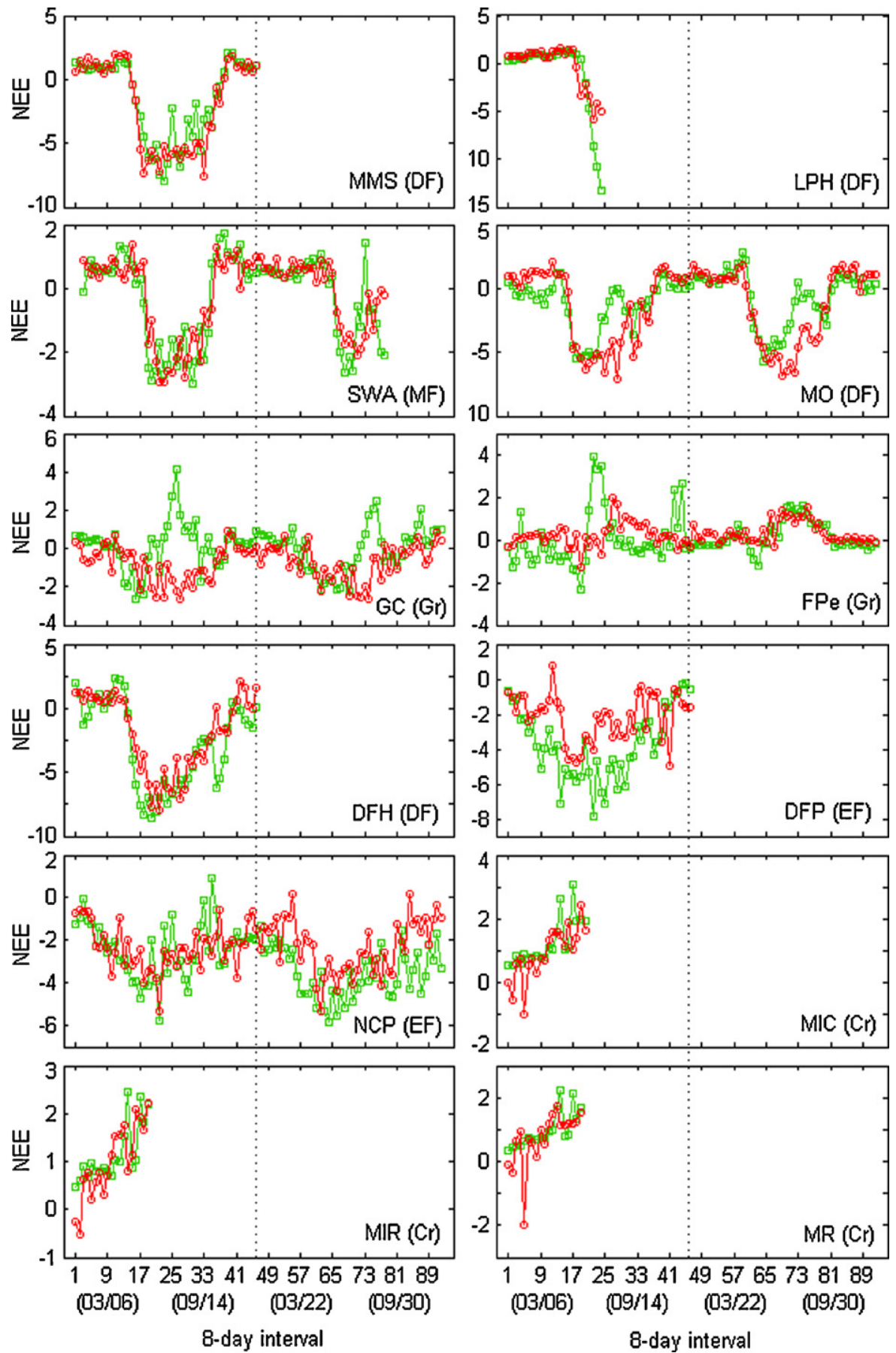

Fig. 6. (Continued) 

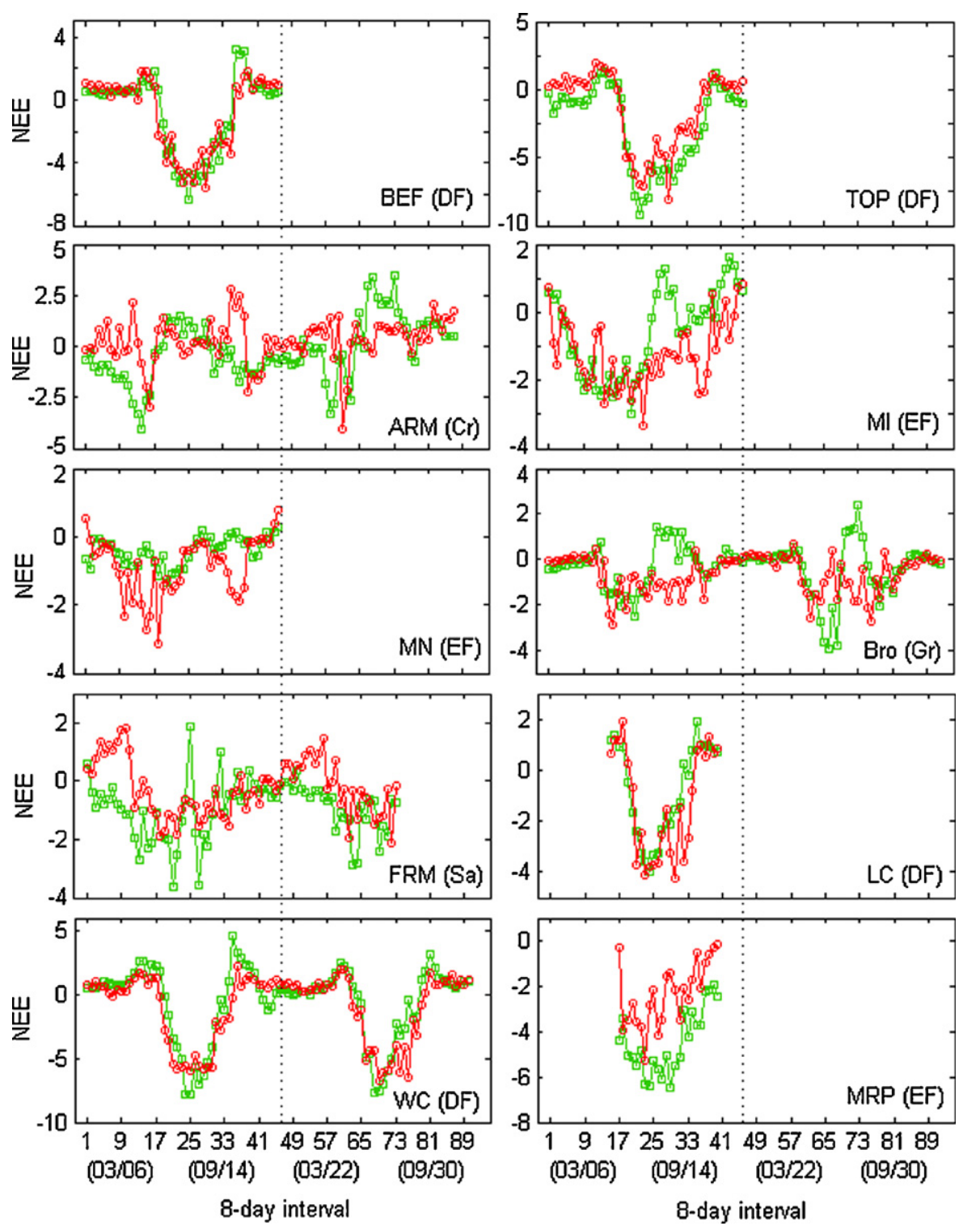

Fig. 6. (Continued).

mean GPP, and the inclusion of cloudy days within 8-day intervals had less effect on GPP than expected. However, increased diffuse radiation under cloudy conditions could result in higher light use efficiency and higher GPP (Gu et al., 2002). The compositing process may exclude high EVI values that represented high fPAR, therefore leading to lower carbon uptake estimates. On the other hand, the compositing process may also exclude low EVI and LST values, thereby affecting NEE estimates. Therefore, the exclusion of days with high and low values could lead to underestimation and overestimation of NEE values, respectively.

We averaged the estimated and observed 8-day NEE for each Ameriflux site and examined the relationship between the estimated and observed mean 8-day NEE across the sites (Fig. 7). The model estimated NEE reasonably well at the site level $(r=0.86, p<0.001)$. Overall, in absolute magnitude, the model underestimated NEE. The performance of the model also varied with site. On average, some sites were carbon sources, whereas other sites were carbon sinks. Large overestimation of carbon uptake occurred at the Toledo Oak Openings site $(\mathrm{OH})$, whereas large underestimation of carbon uptake occurred at Mature Red Pine (WI), Duke Forest Loblolly Pine (NC), Duke Forest Hardwood (NC), and North Carolina Loblolly Pine (NC). Large overestimation of carbon release occurred at Audubon Research Ranch (AZ), ARM Oklahoma (OK), and Freeman Ranch Mesquite (TX), whereas large underestimation of carbon release occurred at Mead Irrigated (NE), Goodwin Creek (MS), and Austin Cary (FL).

We also averaged our estimated and observed 8-day NEE over all AmeriFlux sites for each vegetation type (i.e., biome), and examined the relationship between estimated and observed NEE across the vegetation types (Fig. 8). The model predicted NEE at the biome level very well $(r=0.97, p<0.001)$. Again, in absolute magnitude, the model underestimated NEE. The performance of the model also varied with vegetation 


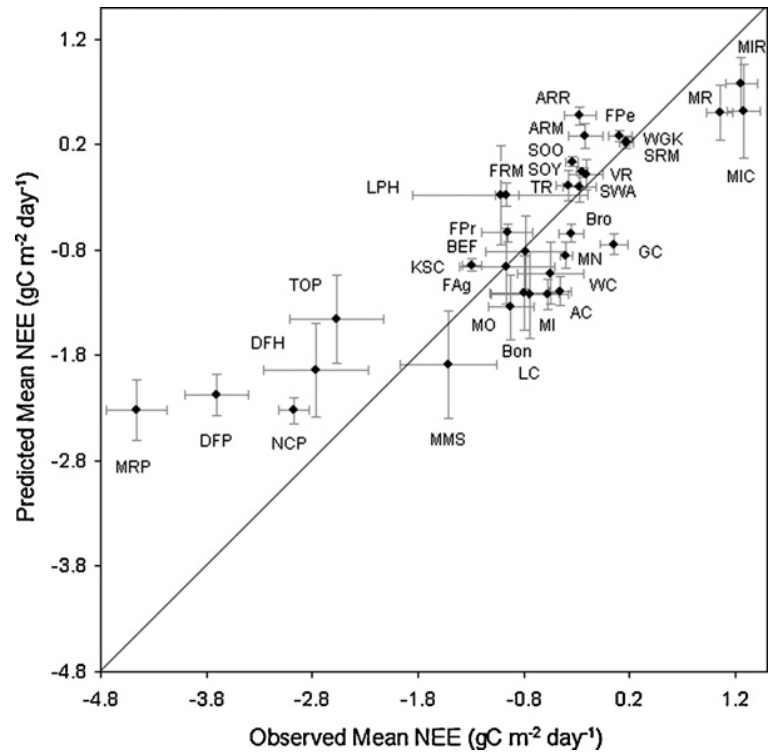

Fig. 7 - Scatterplot of observed mean NEE versus predicted mean NEE across the Ameriflux sites. Error bars are standard errors (defined as the standard deviation divided by the square root of the number of observations) of the observed and predicted 8-day mean NEE. Abbreviations of Ameriflux sites are given in Table 1. For a given site, the mean NEE values did not necessarily represent the fluxes averaged over the entire 2-year period 2005-2006. The temporal coverage of NEE data for each site is provided in Fig. 6.

type. In absolute magnitude, large overestimation occurred for evergreen forests and shrublands.

Our study demonstrated that MODIS data have great potential for scaling up eddy flux NEE data to continental scales across a variety of vegetation types. Unlike GPP (Heinsch et al., 2006; Yang et al., 2007), NEE is much more difficult to estimate because the transient carbon pools and associated heterotrophic respiration are difficult to estimate (Running et al., 2004; Mahadevan et al., 2008). The performance of our model for estimating NEE is encouraging, given the diversity in ecosystem types, age structures, fire and insect disturbances, and management practices. In future research, additional explanatory variables should be selected to better account for live and dead vegetation carbon pools, and other factors that influence decomposition of woody detritus and soil respiration.

\subsection{Continental-scale estimation of NEE}

We estimated NEE for each $1 \mathrm{~km} \times 1 \mathrm{~km}$ cell across the conterminous U.S. for each 8-day interval over the period from January 2005 to February 2006. Fig. 9 shows examples of 8-day NEE maps that we produced for the conterminous U.S. from January through December in 2005. For each month, the second 8-day NEE map was shown here. The predictive model trained at the Ameriflux sites generally captured the expected spatiotemporal patterns of NEE. The majority of the conterminous U.S. released carbon or were nearly carbon

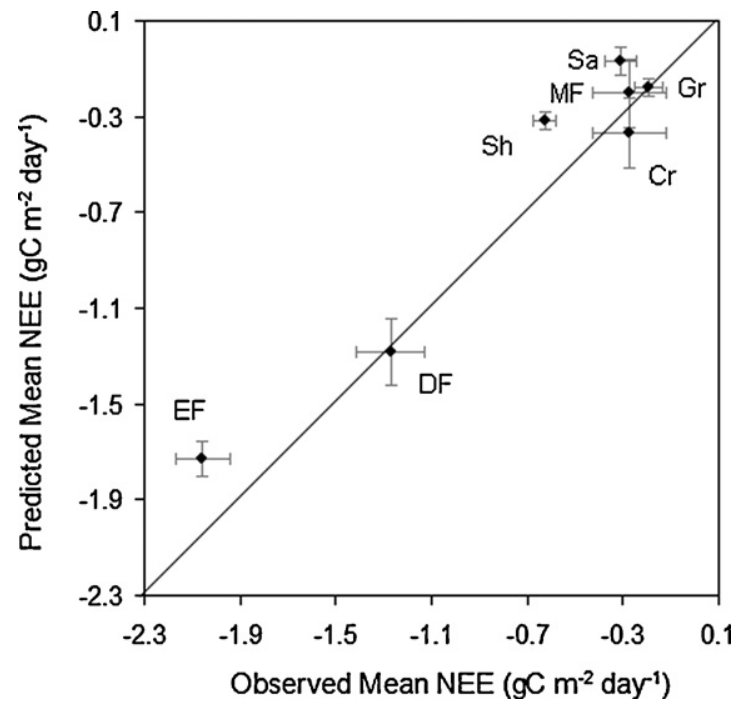

Fig. 8 - Scatterplot of observed mean NEE versus predicted mean NEE across biomes: evergreen forests (EF), deciduous forests (DF), mixed forests (MF), shrublands (Sh), savannas (Sa), grasslands (Gr), and croplands ( $\mathrm{Cr}$ ). Error bars are standard errors (defined as the standard deviation divided by the square root of the number of observations) of the observed and predicted 8-day mean NEE.

neutral in winter months (December-February) because at this time of the year the canopies of most ecosystems were dormant; in summer months (June-August), ecosystems in the East assimilated carbon from the atmosphere, whereas many areas in the West released carbon, possibly due to summer drought effects on NEE. In fall months (SeptemberNovember), ecosystems in the East assimilated less carbon than in the summer months as vegetation began to senesce and days became shorter. Some ecosystems, particularly evergreen forests in the Pacific Northwest and California, assimilated carbon from the atmosphere throughout the year. Douglas-fir, a major species in the Pacific Northwest and California, is known to be highly plastic and able to photosynthesize in winter when temperatures are above freezing.

We aggregated 8-day NEE estimates for each season in 2005 (Fig. 10). Our NEE estimates exhibited strong seasonal fluctuations, agreeing with previous studies (e.g., Falge et al., 2002). Our NEE estimates also varied substantially over space. In the spring (March-May), many areas in the eastern half of the conterminous U.S. including the Southeast and the Gulf Coast assimilated carbon from the atmosphere. The growing season of these ecosystems started in the mid- to late-spring, and GPP quickly exceeded $R_{e}$, leading to net carbon uptake in the entire season. By contrast, the Upper Great Lakes region, the northern Great Plains, and the New England region released carbon. The Upper Great Lakes region and the northern Great Plains are dominated by croplands with most crops planted between April and June (corn planted between April and mid-May; soybeans between mid-May and mid-June; and sorghum between late May and late June; Shroyer et al., 


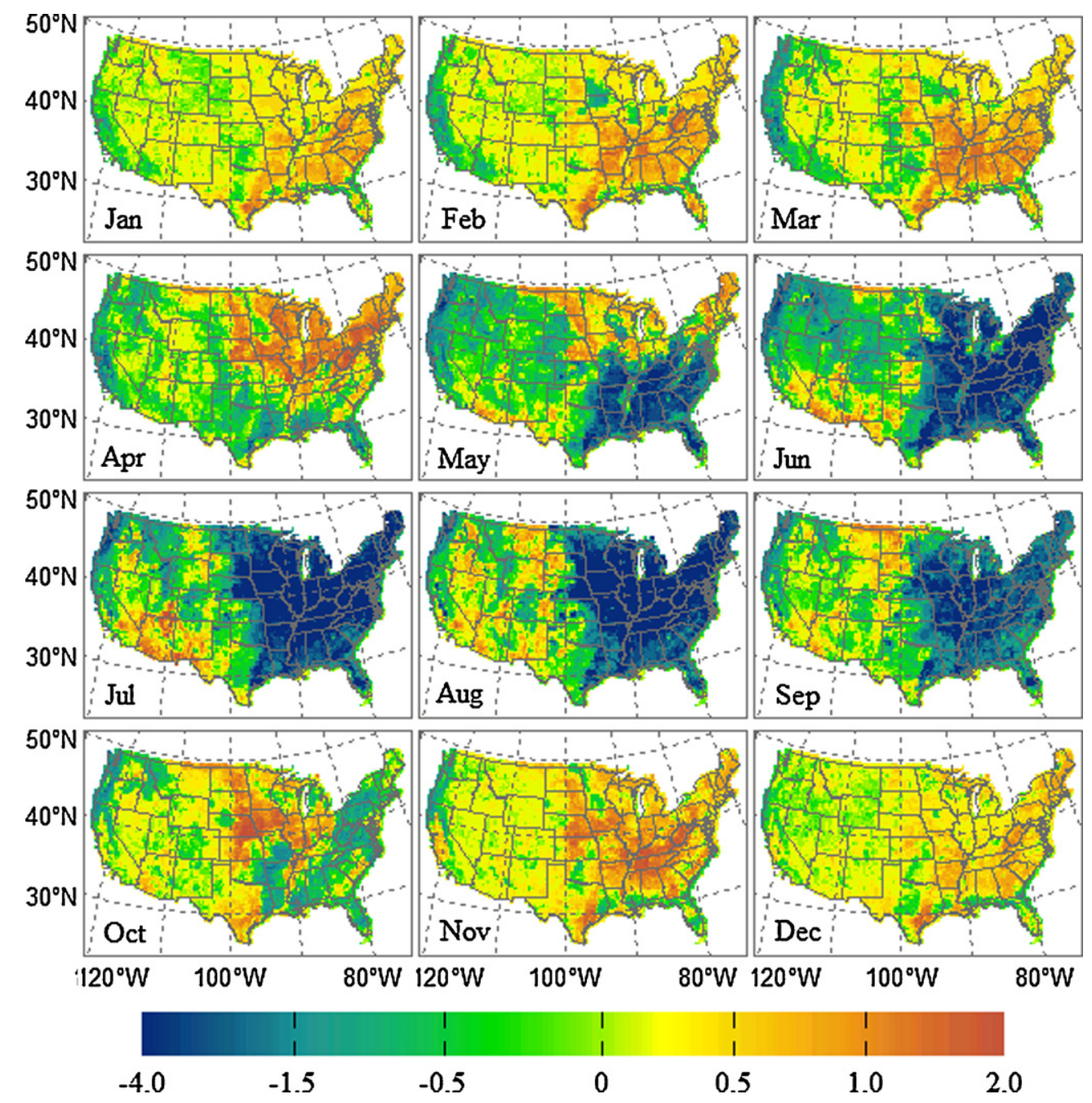

Fig. 9 - Examples of predicted 8-day NEE for the conterminous U.S. from January through December in 2005. For each month, the second 8-day NEE map is shown here. The units are $\mathrm{gC} \mathrm{m}^{-2} \mathrm{day}^{-1}$. Positive values indicate carbon release, and negative values indicate carbon uptake.

1996). Crops were sparse in the beginning of the growing season and $R_{\mathrm{e}}$ exceeded GPP, thereby leading to carbon releases. The New England region and the northern portion of the Upper Great Lakes region are dominated by temperateboreal transitional forests, and their relatively late greenup due to low air temperatures led to carbon releases in the spring. Many regions in the western half of the conterminous U.S. also released carbon in the spring because of the sparse vegetation and the dominance of $R_{e}$ over GPP. The Pacific Coast assimilated carbon even in the spring because the dominant evergreen forests in the region assimilated carbon due to mild temperatures and moist conditions (Anthoni et al., 2002). The Mediterranean regions in California also assimilated carbon in the spring. The Mediterranean climate is characterized by mild winter temperatures concomitant with the rainy season as opposed to severe summer droughts and heat (Barbour and Minnich, 2000). These ecosystems assimilated carbon because of precipitation surplus and relatively warm temperatures in the spring (Xu and Baldocchi, 2004; Ma et al., 2007).

In the summer months (June-August), the eastern half of the conterminous U.S. assimilated carbon because GPP far exceeded $R_{\mathrm{e}}$ owing to favorable temperature and soil moisture conditions. By contrast, a vast majority of the land across the western counterpart released carbon, including the Great Basin, the Colorado Plateau, and the western Great Plains. The 2005 summer drought affected these regions (National Climatic Data Center, 2008) and reduced GPP, whereas the high temperatures increased $R_{e}$, leading to net carbon releases. Some other regions in the West also assimilated carbon, including the northern Rocky Mountains and the Pacific Coast. Some Mediterranean ecosystems in California also released carbon due to precipitation deficits in the summer.

In the fall (September-November), the Southeast and the Gulf Coast still assimilated carbon, but net carbon uptake rates substantially decreased relative to those in the summer. This is because vegetation began to senesce in these regions in the fall. The Upper Great Lakes region and the Great Plains largely released carbon due to the harvesting of crops. The majority of the land across the West including the Great Plains, the Great Basin, and the Colorado Plateau released carbon. The northern Pacific Coast, however, still absorbed 


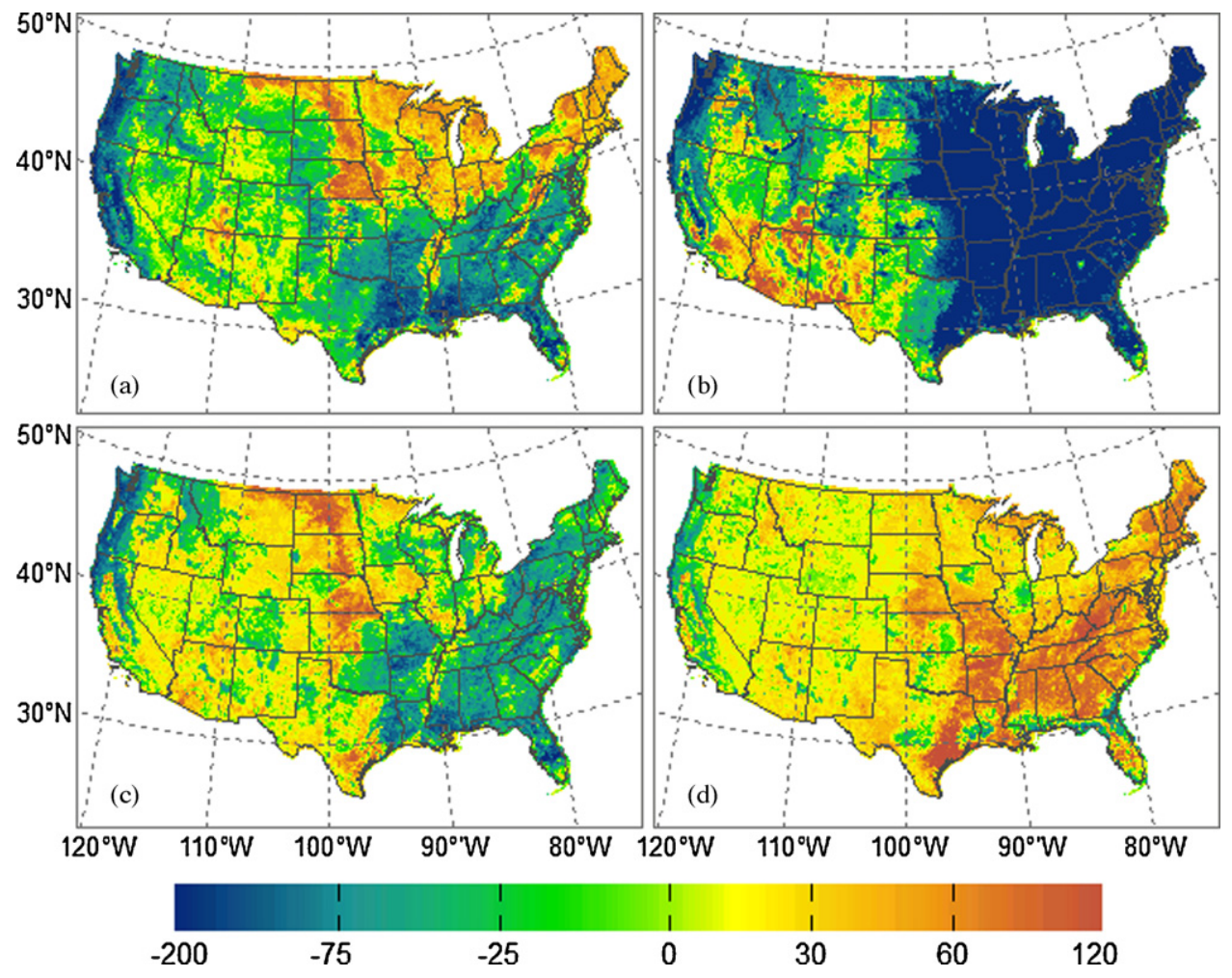

Fig. 10 - Predicted NEE for each season in 2005: (a) spring (March-May); (b) summer (June-August); (c) fall (SeptemberNovember); (d) winter (December-February). The units are $\mathrm{gC} \mathrm{m}^{-2}$ season ${ }^{-1}$. Positive values indicate carbon release, and negative values indicate carbon uptake.

carbon. The Mediterranean ecosystems in California continued releasing carbon as the dry season spanned into the fall.

In the winter (December-February), the vast majority of the conterminous U.S. released carbon as the canopies of most ecosystems were dormant at this season of the year. Some regions in the Pacific Coast, however, assimilated carbon even in the winter because of the dominance of evergreen forests and mild temperatures in the regions (Waring and Franklin, 1979). This agreed with the finding of Anthoni et al. (2002) that old-growth ponderosa pine in Oregon slightly assimilated carbon in the winter season. For the Mediterranean ecosystems in California, a smaller part of the region released carbon into the atmosphere relative to the fall as the wet season started in the winter.

The trajectory of the mean 8-day NEE $\left(\mathrm{gC} \mathrm{m}^{-2}\right.$ day $\left.^{-1}\right)$ for each vegetation type over the entire conterminous U.S. throughout 2005 (Fig. 11a) showed that deciduous forests, croplands, savannas, and mixed forests had large intraannual variability in NEE, whereas evergreen forests, grasslands, and shrublands exhibited much less variability. The seasonal patterns of NEE were determined by the seasonal differences in LAI, physiological capacity, meteorological conditions, growing season length, soil temperature, moisture status, and management practices (Falge et al., 2002). In the late fall, winter, and early spring, on average, the U.S. terrestrial ecosystems released carbon; taken separately, only evergreen forests and grasslands assimilated carbon during this time. Among vegetation types exhibiting positive NEE values, deciduous forests had the highest values, followed by mixed forests; croplands exhibited intermediate values; shrublands and savannas exhibited lowest values while evergreen forests still assimilated carbon. During the growing season, on average, the U.S. terrestrial ecosystems strongly assimilated carbon; taken separately, only shrublands released carbon because of high temperatures and low soil moisture conditions. Among vegetation types assimilating carbon, the highest absorption rates occurred for deciduous forests, followed by croplands, savannas, and mixed forests; intermediate rates occurred for evergreen forests; the lowest rates occurred for grasslands. Baldocchi et al. (2001) showed that the net $\mathrm{CO}_{2}$ exchange of temperate deciduous forests increases by about $5.7 \mathrm{gC} \mathrm{m}^{2}$ day $^{-1}$ for each additional day that the growing season, defined as the period over which mean daily $\mathrm{CO}_{2}$ exchange is negative due to net uptake by ecosystems, is extended. We found that on average, the $\mathrm{CO}_{2}$ exchange of deciduous and evergreen forests across the conterminous U.S. increased 3.6 and $1.2 \mathrm{gC} \mathrm{m}^{-2}$ day $^{-1}$ for each additional day that the growing season is extended, respectively. Our continental-scale estimate for deciduous forests was 37\% lower than that estimated by Baldocchi et al. (2001) likely because our estimate was based on all the areas covered by deciduous forests encompassing the full range of productivity.

The trajectory of the total 8-day NEE $\left(\mathrm{TgC} \mathrm{day}^{-1}\right)$ over the conterminous U.S. (Fig. 11b) showed clear dependence on vegetation type. The differences in the trajectories of total 8day NEE among vegetation types were different from those of mean 8-day NEE because of the differences in the areas among 


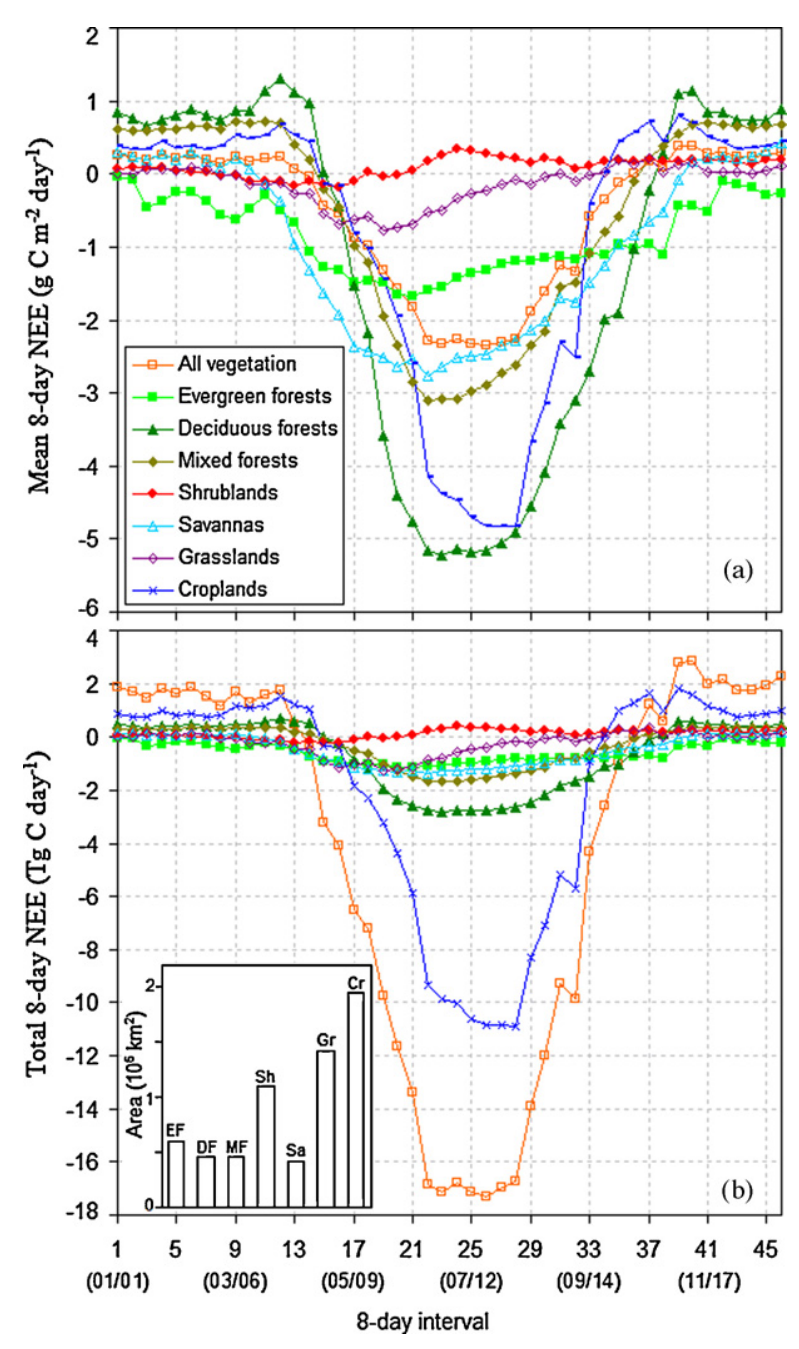

Fig. 11 - Predicted mean and total 8-day NEE for each vegetation type in the conterminous U.S. in 2005. (a) Mean 8-day NEE (gC m ${ }^{-2}$ day $^{-1}$ ); (b) total 8-day NEE $\left(\mathrm{TgC} \mathrm{day}^{-1}\right.$ ). Inset in plot (b) indicates the area $\left(10^{6} \mathrm{~km}^{2}\right)$ of each vegetation type: evergreen forests (EF), deciduous forests (DF), mixed forests (MF), shrublands (Sh), savannas (Sa), grasslands $(\mathrm{Gr})$, and croplands $(\mathrm{Cr})$. For $\mathrm{x}$-axis, the starting dates (month/day) of every two 8-day intervals were given in parentheses under interval numbers.

vegetation types (Fig. 11b). In the late fall, winter, and early spring, the U.S. terrestrial ecosystems released carbon (1$2 \mathrm{TgC}$ day $^{-1}$ ). Taken separately, croplands, deciduous forests, and mixed forests released carbon, whereas evergreen forests assimilated carbon; shrublands, savannas, and grasslands, however, were nearly carbon neutral. During the growing season, the U.S. terrestrial ecosystems assimilated carbon, with peak total NEE of $-17 \mathrm{TgC}$ day $^{-1}$. All vegetation types except shrublands assimilated carbon. In absolute magnitudes, the highest total NEE ( $\approx 10 \mathrm{TgC}$ day $^{-1}$ ) occurred for croplands; the intermediate values occurred for deciduous forests, savannas, and mixed forests; the lowest values occurred for evergreen forests and grasslands. By contrast, shrublands released carbon. Total 8-day NEE also showed largest intra-annual variability for croplands, intermediate variability for deciduous forests, savannas, and mixed forests, and lowest variability for evergreen forests, grasslands, and shrublands.

\section{Summary and conclusions}

We combined MODIS and NEE data from 42 AmeriFlux sites involving a variety of vegetation types to develop a predictive NEE model using a modified regression tree approach. The model was trained and validated using eddy flux NEE data over the periods 2000-2004 and 2005-2006, respectively. The model estimated NEE well at the site level. We then applied the model to estimate NEE for each $1 \mathrm{~km} \times 1 \mathrm{~km}$ cell across the conterminous U.S. for each 8-day period in 2005. The model generally captured the expected spatial and seasonal patterns of NEE. Our study demonstrated that our empirical approach along with MODIS data have great potential for scaling up Ameriflux NEE measurements to the continental scale. Our approach can be applied to the entire North America, other geographical regions including Europe, Southeast Asia, and South America, or to the globe scale, and to produce continuous NEE estimates over regions, continents, or the globe. This approach can also be used to scale other fluxes including GPP and evapotranspiration to large areas.

Our wall-to-wall NEE estimates across the conterminous U.S. provided an independent dataset from simulations by biogeochemical modeling and inverse modeling for examining the spatiotemporal patterns of NEE and constraining U.S. terrestrial carbon sinks/sources. Our estimates have advantages over these model simulations by taking advantage of NEE measurements from a number of Ameriflux sites involving representative U.S. ecosystems. Moreover, our scaling-up approach implicitly considered the effects of climate variability and extreme climate events. Although our NEE estimates could not capture the immediate emissions of $\mathrm{CO}_{2}$ due to the burning of biomass in wildfires, our estimates could partly account for the carbon fluxes following the disturbances because the MODIS data we used provide real-time observations of ecosystems. Compared to inverse modeling techniques, our approach provided estimates at high spatial $(1 \mathrm{~km} \times 1 \mathrm{~km})$ and temporal (8-day) resolutions. In addition, NEE is notoriously difficult to quantify over large areas (Running et al., 2004), and the accuracy of simulated NEE for regions and continents by biogeochemical models is poorly known due to lack of spatially explicit, independent validation data sets. Our estimates may also provide an independent validation data set for these model simulations. We will extend our NEE estimates to the entire MODIS era (2000-present) for the conterminous U.S., which will provide a valuable dataset for examining the interannual variability of the U.S. terrestrial carbon uptake.

The Ameriflux sites provide valuable measurements of ecosystem carbon exchange for examining terrestrial carbon dynamics (Law, 2006, 2007). Our study demonstrated that the Ameriflux measurements could be used to examine continental-scale carbon dynamics, and the continuing operation of the Ameriflux network will continue to improve our understanding of the impacts of climate variability, disturbances, and management practices on terrestrial carbon cycling. Our study also suggested that the current Ameriflux network should be augmented by establishing more sites for 
certain biomes in the UMD classification system (Table 1), including open shrublands, savannas, grasslands, and croplands. The augmentation should enable the differentiation of open shrublands from closed shrublands, woody savannas from savannas, and $\mathrm{C}_{3}$ from $\mathrm{C}_{4}$ plants in scaling-up studies, thereby improving the estimation of carbon fluxes over large areas.

\section{Acknowledgements}

The work of J. Xiao and Q. Zhuang was partly funded by the National Science Foundation (NSF) Carbon and Water Program (EAR-0630319). We thank the U.S. Department of Energy Biological and Environmental Research, Terrestrial Carbon Program (Award \#DE-FG02-04ER63917) for funding Dr. B.E. Law to develop the AmeriFlux network protocols and database design for the network, and the Office of Science, U.S. Department of Energy, through the Midwestern Regional Center of the National Institute for Global Environmental Change under Cooperative Agreements No. DE-FC0390ER610100 for funding P.S. Curtis. We thank the principal investigators of the MODIS data products including A.R. Huete, Z. Wan, R.B. Myneni, and E.F. Vermote and other contributors as well as the Oak Ridge National Laboratory (ORNL), Distributed Active Archive Center (DAAC), and the Earth Observing System (EOS) Data Gateway for making these products available. We also thank T.A. Boden at the Carbon Dioxide Information Analysis Center, ORNL, S.K.S. Vannan at the ORNL DACC, M. Zhao at the University of Montana, and Z. Wan at the University of California, Santa Barbara, for helpful discussion about Ameriflux data, MODIS ASCII subsets, MODIS Quality Assurance (QA) flags, and MODIS LST, respectively. The PRISM climate database was provided by the PRISM Group, Oregon State University (http:// www.prismclimate.org). Computing support was provided by the Rosen Center for Advanced Computing, Purdue University.

\section{REFERENCES}

AmeriFlux, 2007. AmeriFlux Network http://public.ornl.gov/ ameriflux/ (visited on 10/04/07).

Anthoni, P.M., Unsworth, M.H., Law, B.E., Irvine, J., Baldocchi, D.D., Tuyl, S.V., Moore, D., 2002. Seasonal differences in carbon and water vapor exchange in young and old-growth ponderosa pine ecosystems. Agric. For. Meteorol. 111, 203-222.

Asrar, G., Fuchs, M., Kanemasu, E.T., Hatfield, J.L., 1984. Estimating of absorbed photosynthesis radiation and leaf area index from spectral reflectance in wheat. Agron. J. 76, 300-306.

Baldocchi, D., Falge, E., Gu, L., Olson, R., Hollinger, D., Running, S., Anthoni, P., Bernhofer, C., Davis, K., Evans, R., Fuentes, J., Goldstein, A., Katul, G., Law, B., Lee, X., Malhi, Y., Meyers, T., Munger, W., Oechel, W., Paw U, K.T., Pilegaard, K., Schmid, H.P., Valentini, R., Verma, S., Vesala, T., Wilson, K., Wofsy, S., 2001. FLUXNET: a new tool to study the temporal and spatial variability of ecosystem-scale carbon dioxide, water vapor, and energy flux densities. Bull. Am. Meteorol. Soc. 82, 2415-2434.
Barbour, M., Minnich, B., 2000. California upland forests and woodlands. In: Barbour, M., Billings, W. (Eds.), North American Terrestrial Vegetation. 2nd ed. Cambridge University Press, Cambridge, UK, pp. 161-202.

Belward, A., Loveland, T. 1996. The DIS $1 \mathrm{~km}$ land cover data set. Global Change, The IGBP Newsletter, 27.

Ceccato, P., Gobron, N., Flasse, S., Pinty, B., Tarantola, S., 2002. Designing a spectral index to estimate vegetation water content from remote sensing data. Part 1. Theoretical approach. Remote Sens. Environ. 82, 188-197.

Clark, K.L., Gholz, H.L., Moncrieff, J.B., Cropley, F., Loescher, H.W., 1999. Environmental controls over net carbon dioxide from contrasting Florida ecosystems. Ecol. Appl. 9, 936-948.

Clark, K.L., Gholz, H.L., Castro, M.S., 2004. Carbon dynamics along a chronosequence of slash pine plantations in $\mathrm{N}$. Florida. Ecol. Appl. 4, 1154-1171.

Cook, B.D., Davis, K.J., Wang, W., Desai, A., Berger, B.W., Teclaw, R.M., Martin, J.G., Bolstad, P.V., Bakwin, P.S., Yi, C., Heilman, W., 2004. Carbon exchange and venting anomalies in an upland deciduous forest in northern Wisconsin, USA. Agric. For. Meteorol. 126, 271-295.

DeFries, R.S., Houghton, R.A., Hansen, M.C., Field, C.B., Skole, D., Townshend, J., 2002. Carbon emissions from tropical deforestation and regrowth based on satellite observations for the 1980s and 1990s. PNAS 99, 14256-14261.

Deng, F., Chen, J.M., Ishizawa, M., Yuen, C.-W., Mo, G., Higuchi, K., Chan, D., Maksyutov, S., 2007. Global monthly $\mathrm{CO}_{2}$ flux inversion with a focus over North America. Tellus 59B, 179-190.

Denning, A.S., Gollatz, J.G., Zhang, C., Randall, D.A., Berry, J.A., Sellers, P.J., Colello, G.D., Dazlich, D.A., 1996. Simulations of terrestrial carbon metabolism and atmospheric $\mathrm{CO}_{2}$ in a general circulation model. Part 1. Surface carbon fluxes. Tellus 48B, 521-542.

Desai, A.R., Bolstad, P.V., Cook, B.D., Davis, K.J., Carey, E.V., 2005. Comparing net ecosystem exchange of carbon dioxide between an old-growth and mature forest in the upper Midwest, USA. Agric. For. Meteorol. 128, 33-55.

Dore, S., Hymus, G.J., Johnson, D.P., Hinkle, C.R., Valentini, R., Drake, B.G., 2003. Cross validation of open-top chamber and eddy covariance measurements of ecosystem $\mathrm{CO}_{2}$ exchange in a Florida scrub-oak ecosystem. Global Change Biol. 9, 84-95.

Falge, E., Baldocchi, D., Olson, R., Anthoni, P., Aubinet, M., Bernhofer, C., Burba, G., Ceulemans, R., Clement, R., Dolman, H., Granier, A., Gross, P., Grunwald, T., Hollinger, D., Jensen, N.-O., Katul, G., Keronen, P., Kowalski, A., Lai, C.T., Law, B.E., Meyers, T., Moncrieff, J., Moors, E., Munger, J.W., Pilegaard, K., Rannik, U., Rebmann, C., Suyker, A., Tenhunen, J., Tu, K., Verma, S., Vesala, T., Wilson, K., Wofsy, S., 2001. Gap filling strategies for defensible annual sums of net ecosystem exchange. Agric. For. Meteorol. 107, 43-69.

Falge, E., Baldocchi, D., Tenhunen, J., Aubinet, M., Bakwin, P., Berbigier, P., Bernhofer, C., Burba, G., Clement, R., Davis, K.J., Elbers, J.A., Goldstein, A.H., Grelle, A., Granier, A., Guðmundsson, J., Hollinger, D., Kowalski, A.S., Katul, G., Law, B.E., Malhi, Y., Meyers, T., Monson, R.K., Munger, J.W., Oechel, W., Paw U, K.T., Pilegaard, K., Rannik, U., Rebmann, C., Suyker, A., Valentini, R., Wilson, K., Wofsy, S., 2002. Seasonality of ecosystem respiration and gross primary production as derived from FLUXNET measurements. Agric. For. Meteorol. 113, 53-74.

Falk, M., Wharton, S., Schroeder, M., Ustin, S., Paw U, K.T., 2008. Flux partitioning in an old-growth forest: seasonal and interannual dynamics. Tree Physiol. 28, 509-520.

Fan, S.M., Gloor, M., Mahlman, J., Pacala, S., Sarmiento, J., Takahashi, T., Tans, P., 1998. A large terrestrial carbon sink in North America implied by atmospheric and oceanic carbon dioxide data and models. Science 282, 442-446. 
Fensholt, R., Sandholt, I., 2003. Derivation of a shortwave infrared water stress index from MODIS near- and shortwave infrared data in a semiarid environment. Remote Sens. Environ. 87, 111-121.

Field, C.B., Randerson, J.T., Malmstrom, C.M., 1995. Global net primary production: combining ecology and remote sensing. Remote Sens. Environ. 51, 74-88.

FLUXNET, 2008. FLUXNET Project. http://daac.ornl.gov/ FLUXNET (visited on 01/02/08).

Friedl, M.A., McIver, D.K., Hodges, J.C.F., Zhang, X.Y., Muchoney, D., Strahler, A.H., Woodcock, C.E., Gopal, S., Schneider, A., Cooper, A., Baccini, A., Gao, F., Schaaf, C., 2002. Global land cover mapping from MODIS: algorithms and early results. Remote Sens. Environ. 83, 287-302.

Gao, B.C., 1996. NDWI-a normalized difference water index for remote sensing of vegetation liquid water from space. Remote Sens. Environ. 58, 257-266.

Göckede, M., Foken, T., Aubinet, M., Aurela, M., Banza, J., Bernhofer, C., Bonnefond, J.M., Brunet, Y., Carrara, A., Clement, R., Dellwik, E., Elbers, J., Eugster, W., Fuhrer, J., Granier, A., Grünwald, T., Heinesch, B., Janssens, I.A., Knohl, A., Koeble, R., Laurila, T., Longdoz, B., Manca, G., Marek, M., Markkanen, T., Mateus, J., Matteucci, G., Mauder, M., Migliavacca, M., Minerbi, S., Moncrieff, J., Montagnani, L., Moors, E., Ourcival, J.-M., Papale, D., Pereira, J., Pilegaard, K., Pita, G., Rambal, S., Rebmann, C., Rodrigues, A., Rotenberg, E., Sanz, M.J., Sedlak, P., Seufert, G., Siebicke, L., Soussana, J.F., Valentini, R., Vesala, T., Verbeeck, H., Yakir, D., 2008. Quality control of CarboEurope flux data. Part 1. Coupling footprint analyses with flux data quality assessment to evaluate sites in forest ecosystems. Biogeosciences 5, 433-450.

Goodale, C.L., Apps, M.J., Birdsey, R.A., Field, C.B., Heath, L.S., Houghton, R.A., Jenkins, J.C., Kohlmaier, G.H., Kurz, W.A., Liu, S., Nabuurs, G.-J., Nilsson, S., Shvidenko, A.Z., 2002. Forest carbon sinks in the Northern Hemisphere. Ecol. Appl. 12, 891-899.

Gough, C.M., Vogel, C.S., Schmid, H.P., Su, H.-B., Curtis, P.S., 2008. Multi-year convergence of biometric and meteorological estimates of forest carbon storage. Agric. For. Meteorol. 148, 158-170.

Gu, L., Baldocchi, D., Verma, S.B., Black, T.A., Vesala, T., Falge, E.M., Dowty, P.R., 2002. Advantages of diffuse radiation for terrestrial ecosystem productivity. J. Geophys. Res. 107, 4050, doi:10.1029/2001JD001242.

Gu, L., Meyers, T., Pallardy, S.G., Hanson, P.J., Yang, B., Heuer, M., Hosman, K.P., Liu, Q., Riggs, J.S., Sluss, D., Wullschleger, S.D., 2007. Influences of biomass heat and biochemical energy storages on the land surface fluxes and radiative temperature. J. Geophys. Res. D02107 , doi:10.1029/ 2006JD007425.

Gu, L., Meyers, T., Pallardy, S.G., Hanson, P.J., Yang, B., Heuer, M., Hosman, K.P., Riggs, J.S., Sluss, D., Wullschleger, S.D., 2006. Direct and indirect effects of atmospheric conditions and soil moisture on surface energy partitioning revealed by a prolonged drought at a temperate forest site. J. Geophys. Res. D16102, doi:10.1029/2006JD007161.

Gurney, K.R., Law, R.M., Denning, A.S., Rayner, P.J., Baker, D., Bousquet, P., Bruhwiler, L., Chen, Y.-H., Ciasi, P., Fan, S., Fung, I.Y., Gloor, M., Heimann, M., Higuchi, K., John, J., Maki, T., Maksyutov, S., Masarie, K., Peylin, P., Prather, M., Pak, B.C., Randerson, J., Sarmiento, J., Taguchi, S., Takahashi, T., Yuen, C.-W., 2002. Towards robust regional estimates of $\mathrm{CO}_{2}$ sources and sinks using atmospheric transport models. Nature 415, 626-630.

Heinsch, F.A., Zhao, M., Running, S.W., Kimball, J.S., Nemani, R.R., Davis, K.J., Bolstad, P.V., Cook, B.D., Desai, A.R., Ricciuto, D.M., Law, B.E., Oechel, W.C., Kwon, H.J., Luo, H., Wofsy, S.C., Dunn, A.L., Munger, J.W., Baldocchi, D.D., Xu,
L., Hollinger, D.Y., Richardson, A.D., Stoy, P.C., Siqueira, M.B.S., Monson, R.K., Burns, S.P., Flanagan, L.B., 2006. Evaluation of remote sensing based terrestrial productivity from MODIS using regional tower eddy flux network observations. IEEE Trans. Geosci. Remote Sens. 44, 1908-1925.

Hollinger, D.Y., Goltz, S.M., Davidson, E.A., Lee, J.T., Tu, K., Valentine, H.T., 1999. Seasonal patterns and environmental control of carbon dioxide and water vapor exchange in an ecotonal boreal forest. Global Change Biol. 5, 891-902.

Hollinger, D.Y., Aber, J., Dail, B., Davidson, E.A., Goltz, S.M., Hughes, H., Leclerc, M.Y., Lee, J.T., Richardson, A.D., Rodrigues, C., Scott, N.A., Achuatavarier, D., Walsh, J., 2004 Spatial and temporal variability in forest-atmosphere $\mathrm{CO}_{2}$ exchange. Global Change Biol. 10, 1689-1706.

Hollinger, S.E., Bernacchi, C.J., Meyers, T.P., 2005. Carbon budget of mature no-till ecosystem in North Central Region of the United States. Agric. For. Meteorol. 130, 59-69.

Huang, C., Townshend, J.R.G., 2003. A stepwise regression tree for nonlinear approximation: applications to estimating subpixel land cover. Int. J. Remote Sens. 24, 75-90.

Huete, A.R., Liu, H.Q., Batchily, K., vanLeeuwen, W., 1997. A comparison of vegetation indices global set of TM images for EOS-MODIS. Remote Sens. Environ. 59, 440-451.

Huete, A., Didan, K., Miura, T., Rodriguez, E.P., Gao, X., Ferreira, L.G., 2002. Overview of the radiometric and biophysical performance of the MODIS vegetation indices. Remote Sens. Environ. 83, 195-213.

Hunt, E.R., Rock, B.N., 1989. Detection of changes in leaf water content using near- and middle-infrared reflectances. Remote Sens. Environ. 30, 43-54.

Irvine, J., Law, B.E., Hibbard, K.A., 2007. Postfire carbon pools and fluxes in semiarid ponderosa pine in Central Oregon. Global Change Biol. 13, 1748-1760.

Jackson, T.J., Chen, D., Cosh, M., Li, F., Anderson, M., Walthall, C., Doriaswamy, P., Hunt, E.R., 2004. Vegetation water content mapping using Landsat data derived normalized difference water index for corn and soybeans. Remote Sens. Environ. 92, 475-482.

Jenkins, J.P., Richardson, A.D., Braswell, B.H., Ollinger, S.V., Hollinger, D.Y., Smith, M.-L., 2007. Refining light-use efficiency calculations for a deciduous forest canopy using simultaneous tower-based carbon flux and radiometric measurements. Agric. For. Meteorol. 143, 64-79.

Janssens, I.A., Freibauer, A., Ciais, P., Smith, P., Jabuurs, G.-J., et al., 2003. Europe's terrestrial biosphere absorbs 7 to $12 \%$ of European anthropogenic $\mathrm{CO}_{2}$ emissions. Science 300, 1538-1542.

Law, B.E., 2006. Carbon dynamics in response to climate and disturbance: recent progress from multiscale measurements and modeling in Ameriflux. In: Omasa, K., Nouchi, I., De Kok, L.J. (Eds.), Plant Responses to Air Pollution and Global Change. Springer, Tokyo, Japan, pp. 205-213.

Law, B.E., 2007. AmeriFlux network aids global synthesis. EOS Trans. 88, 286.

Law, B.E., Ryan, M.G., Anthoni, P.M., 1999. Seasonal and annual respiration of a ponderosa pine ecosystem. Global Change Biol. 5, 169-182.

Law, B.E., Sun, O.J., Campbell, J., Tuyl, S.V., Thornton, P.E., 2003. Changes in carbon storage and fluxes in a chronosequence of ponderosa pine. Global Change Biol. 9, 510-524.

Law, B.E., Turner, D., Campbell, J., Sun, O.J., Van Tuyl, S., Ritts, W.D., Cohen, W.B., 2004. Disturbance and climate effects on carbon stocks and fluxes across Western Oregon, USA. Global Change Biol. 10, 1429-1444.

Law, B.E., Turner, D., Lefsky, M., Campbell, J., Guzy, M., Sun, O., Van Tuyl, S., Cohen, W., 2006. Carbon fluxes across regions: observational constraints at multiple scales. In: Wu, J., Jones, B., Li, H., Loucks, O. (Eds.), Scaling and Uncertainty Analysis 
in Ecology: Methods and Applications. Springer, USA, pp. 167-190.

Law, B.E., Waring, R.H., 1994. Remote sensing of leaf area index and radiation intercepted by understory vegetation. Ecol. Appl. 4, 272-279.

Lipson, D.A., Wilson, R.F., Oechel, W.C., 2005. Effects of elevated atmospheric $\mathrm{CO}_{2}$ on soil microbial biomass, activity, and diversity in a chaparral ecosystem. Appl. Environ. Microbiol. 71, 8573-8580.

Ma, S., Baldocchi, D.D., Xu, L., Hehn, T., 2007. Inter-annual variability in carbon dioxide exchange of an oak/grass savanna and open grassland in California. Agric. For. Meteorol. 147, 157-171.

Mahadevan, P., Wofsy, S.C., Matross, D.M., Xiao, X., Dunn, A.L., Lin, J.C., Gerbig, C., Munger, J.W., Chow, V.Y., Gottlieb, E.W., 2008. A satellite-based biosphere parameterization for net ecosystem $\mathrm{CO}_{2}$ exchange: vegetation photosynthesis and respiration model (VPRM). Global Biogeochem. Cyc. 22, GB2005.

Monson, R.K., Turnipseed, A.A., Sparks, J.P., Harley, P.C., ScottDenton, L.E., Sparks, K., Huxman, T.E., 2002. Carbon sequestration in a high-elevation, subalpine forest. Global Change Biol. 8, 459-478.

Moffat, A.M., Papale, D., Reichstein, M., Hollinger, D.Y., Richardson, A.D., Barr, A.G., Beckstein, C., Braswell, B.H., Churkina, G., Desai, A.R., Falge, E., Gove, J.H., Heimann, M., Hui, D., Jarvis, A.J., Kattge, J., Noormets, A., Stauch, V.J., 2007. Comprehensive comparison of gap-filling techniques for eddy covariance net carbon fluxes. Agric. For. Meteorol. 147, 209-232.

Myneni, R.B., Dong, J., Tucker, C.J., Kaufmann, R.K., Kauppi, P.E., Liski, J., Zhou, L., Alexeyev, V., Hughes, M.K., 2001. A large carbon sink in the woody biomass of northern forests. PNAS 98, 14784-14789.

Myneni, R.B., Hoffman, S., Knyazikhin, Y., Privette, J.L., Tian, Y., Wang, Y., Song, X., Zhang, Y., Smith, G.R., Lotsch, A., Friedl, M., Morisette, J.T., Votava, P., Nemani, R.R., Running, S.W., 2002. Global products of vegetation leaf area and fraction absorbed PAR from year one of MODIS data. Remote Sens. Environ. 83, 214-231.

National Climatic Data Center, 2008. http://lwf.ncdc.noaa.gov/ oa/climate/research/2005/perspectives.html (visited on 01/ 28/08).

Noormets, A., Chen, J., Crow, T.R., 2007. Age-dependent changes in ecosystem carbon fluxes in managed forests in northern Wisconsin, USA. Ecosystems 10, 187-203.

Noormets, A., Desai, A.R., Cook, B.D., Euskirchen, E.S., Ricciuto, D.M., Davis, K.J., Bolstad, P.V., Schmid, H.P., Vogel, C.V., Carey, E.V., Su, H.B., Chen, J., 2008a. Moisture sensitivity of ecosystem respiration: comparison of 14 forest ecosystems in the Upper Great Lakes Region, USA. Agric. For. Meteorol. $148,216-230$.

Noormets, A., McNulty, S.G., DeForest, J.L., Sun, G., Li, Q., Chen, J., 2008b. Drought during canopy development has lasting effect on annual carbon balance in a deciduous temperate forest. New Phytol. 179, 818-828.

Noormets, A., McNulty, S.G., Gavazzi, M.J., Sun, G., Domec, J.C., King, J., Chen, J., unpublished. High drought tolerance of carbon fluxes in a coastal plain loblolly pine forest. Global Change Biol.

Oak Ridge National Laboratory Distributed Active Archive Center (ORNL DAAC), 2006. MODIS subsetted land products, Collection 4. Available on-line (http:// www.daac.ornl.gov/MODIS/modis.html) from ORNL DAAC, Oak Ridge, Tennessee, U.S.A. (accessed Month 06, 2007).

Oren, R., Ewers, B.E., Todd, P., Phillips, N., Katul, G., 1998. Water balance delineates the soil layer in which moisture affects canopy conductance. Ecol. Appl. 8, 990-1002.
Oren, R., Hsieh, C.-I., Stoy, P., Albertson, J., McCarthy, H.R., Harrell, P., Katul, G.G., 2006. Estimating the uncertainty in annual net ecosystem carbon exchange: spatial variation in turbulent fluxes and sampling errors in eddy-covariance measurements. Global Change Biol. 12, 883-896.

Pacala, S.W., Hurtt, G.C., Baker, D., Peylin, P., Houghton, R.A., Birdsey, R.A., Heath, L., Sundquist, E.T., Stallard, R.F., Ciais, P., Moorcroft, P., Caspersen, J.P., Shevliakova, E., Moore, B., Kohlmaier, G., Holland, E., Gloor, M., Harmon, M.E., Fan, S.M., Sarmiento, J.L., Goodale, C.L., Schimel, D., Field, C.B., 2001. Consistent land- and atmosphere-based U.S. carbon sink estimates. Science 292, 2316-2320.

Papale, D., Valentini, A., 2003. A new assessment of European forests carbon exchange by eddy fluxes and artificial neural network spatialization. Global Change Biol. 9, 525-535.

Pataki, D.E., Oren, R., 2003. Species difference in stomatal control of water loss at the canopy scale in a bottomland deciduous forest. Adv. Water Res. 26, 1267-1278.

Penuelas, J., Gamon, J.A., Griffin, K.L., Field, C.B., 1993. Assessing community type, plant biomass, pigment composition, and photosynthetic efficiency of aquatic vegetation from spectral reflectance. Remote Sens. Environ. 46, 110-118.

Potter, C.S., Randerson, J.T., Field, C.B., Matson, P.A., Vitousek, P.M., Mooney, H.A., Klosster, S.A., 1993. Terrestrial ecosystem production-a process model based on global satellite and surface data. Global Biogeochem. Cyc. 7, 811-841.

Powell, T.L., Starr, G., Clark, K.L., Martin, T.A., Gholz, H.L., 2005. Ecosystem and understory water and energy exchange for a mature, naturally regenerated pine flatwoods forest in north Florida. Can. J. For. Res. 35, 1568-1580.

Rahman, A.F., Sims, D.A., Cordova, V.D., El-Masri, B.Z., 2005. Potential of MODIS EVI and surface temperature for directly estimating per-pixel ecosystem C fluxes. Geophys. Res. Lett. 32, L19404, doi:10.1029/2005GL024127.

Ranson, K.J., Daughtry, C.S.T., Biehl, L.L., Bauer, M.E., 1985. Sunview angle effects on reflectance factors of corn canopies. Remote Sens. Environ. 18, 147-161.

Reichstein, M., Falge, E., Baldocchi, D., Papale, D., Aubinet, M., Berbigier, P., Bernhofer, C., Buchmann, N., Gilmanov, T., Granier, A., Grunwald, T., Havrankova, K., Ilvesniemi, H., Janous, D., Knohl, A., Laurila, T., Lohila, A., Loustau, D., Matteucci, G., Meyers, T., Miglietta, F., Ourcival, J.M., Pumpanen, J., Rambal, S., Rotenberg, E., Sanz, M., Tenhunen, J., Seufert, G., Vaccari, F., Vesala, T., Yakir, D., Valentini, R., 2005. On the separation of net ecosystem exchange into assimilation and ecosystem respiration: review and improved algorithm. Global Change Biol. 11, 1424-1439.

Richardson, A.D., Hollinger, D.Y., Aber, J.D., Qllinger, S.V., Braswell, B.H., 2007. Environmental variation is directly responsible for short- but not long-term variation in forestatmosphere carbon exchange. Global Change Biol. 13, 788-803.

Richardson, A.D., Mahecha, M.D., Falge, E., Kattge, J., Moffat, A.M., Papale, D., Reichstein, M., Stauch, V.J., Braswell, B.H., Churkina, G., Kruijt, B., Hollinger, D.Y., 2008. Statistical properties of random $\mathrm{CO}_{2}$ flux measurement uncertainty inferred from model residuals. Agric. For. Meteorol. 148, 38-50.

RuleQuest, 2008. http://www.rulequest.com (visited on 10/18/07).

Running, S.W., Hunt, E.R., 1993. Generalization of a forest ecosystem process model for other biomes, Biome-BGC, and an application for global-scale models. Scaling processes between leaf and landscape levels. In: Ehleringer, J.R., Field, C.B. (Eds.), Scaling Physiological Processes: Leaf to Globe. Academic Press, San Diego, pp. 141-158.

Running, S.W., Baldocchi, D.D., Turner, D.P., Gower, S.T., Bakwin, P.S., Hibbard, K.A., 1999. A global terrestrial 
monitoring network integrating tower fluxes, flask sampling, ecosystem modeling and EOS satellite data. Remote Sens. Environ. 70, 108-127.

Running, S.W., Nemani, R.R., Heinsch, F.A., Zhao, M., Reeves, M., Hashimoto, H., 2004. A continuous satellite-derived measure of global terrestrial primary production. BioScience 54, 547-560.

Ryan, M.G., Law, B.E., 2005. Interpreting, measuring, and modeling soil respiration. Biogeochemistry 73, 3-27.

Salajanu, D., Jacobs, D.M., 2005. Assessing biomass and forest area classifications from MODIS satellite data while incrementing the number of FIA data panels. In: Pecora 16 "Global Priorities in Land Remote Sensing", October 23-27, Sioux Falls, South Dakota, 10 pp.

Schmid, H.P., 1994. Source areas for scalars and scalar fluxes. Bound.-Layer Meteorol. 67, 293-318.

Schmid, H.P., 2002. Footprint modeling for vegetation atmospheric exchange studies: a review and perspective. Agric. For. Meteorol. 113, 159-183.

Schmid, H.P., Grimmond, C.S.B., Cropley, F., Offerle, B., Su, H.B., 2000. Measurements of $\mathrm{CO}_{2}$ and energy fluxes over a mixed hardwood forest in the mid-western United States. Agric. For. Meteorol. 103, 357-374.

Schmidt, K.S., Skidmore, A.K., 2003. Spectral discrimination of vegetation types in a coastal wetland. Remote Sens. Environ. 85, 92-108.

Sellers, P.J., Randall, D.A., Betts, A.K., Hall, F.G., Berry, J.A., Collatz, G.J., Denning, A.S., Mooney, H.A., Nobre, C.A., Sato, N., Field, C.B., Henderson-sellers, A., 1997. Modeling the exchanges of energy, water, and carbon between continents and the atmosphere. Science 275, 502-509.

Shroyer, J.P., Thompson, C., Brown, R., Ohlenbach, P.D., Fjell, D.L., Staggenborg, S., Duncan, S., Kilgore, G.L., 1996. Kansas Crop Planting Guide, vol. L-818. Kansas State University, Manhattan, KS, pp. 2.

Sims, D.A., Rahman, A.F., Cordova, V.D., Baldocchi, D.D., Flanagan, L.B., Goldstein, A.H., Hollinger, D.Y., Misson, L., Monson, R.K., Schmid, H.P., Wofsy, S.C., Xu, L., 2005. Midday values of gross $\mathrm{CO}_{2}$ flux and light use efficiency during satellite overpasses can be used to directly estimate eightday mean flux. Agric. For. Meteorol. 131, 1-12.

Tans, P.P., Fung, I.Y., Takahashi, T., 1990. Observational constraints on the global atmospheric $\mathrm{CO}_{2}$ budget. Science 247, 1431-1438.

Thornton, P.E., Law, B.E., Gholz, H.L., Clark, K.L., Falge, E., Ellsworth, D.S., Goldstein, A.H., Monson, R.K., Hollinger, D., Falk, M., Chen, J., Sparks, J.P., 2002. Modeling and measuring the effects of disturbance history and climate on carbon and water budgets in evergreen needleleaf forests. Agric. For. Meteorol. 113, 185-222.

Urbanski, S., Barford, C., Wofsy, S., Kucharik, C., Pyle, E., Budney, J., McKain, K., Fitzjarrald, D., Czikowsky, M., Munger, J.W., 2007. Factors controlling $\mathrm{CO}_{2}$ exchange on timescales from hourly to decadal at Harvard Forest. J. Geophys. Res. 112, G02020, doi:10.1029/2006JG000293.

Verma, S.B., Dobermann, A., Cassman, K.G., Walters, D.T., Knops, J.M., Arkebauer, T.J., Suyker, A.E., Burba, G.G., Amos, B., Yang, H., Ginting, D., Hubbard, K.G., Gitelson, A.A., Walter-Shea, E.A., 2005. Annual carbon dioxide exchange in irrigated and rainfed maize-based agroecosystems. Agric. For. Meteorol. 131, 77-96.
Vermote, E.F., Vermeulen, A., 1999. MODIS Algorithm Technical Background Document-Atmospheric Correction Algorithm: Spectral Reflectances (MOD09), Version 4.0 http://modis.gsfc.nasa.gov/data/atbd/atbd_mod08.pdf.

Wan, Z., Zhang, Y., Zhang, Q., Li, Z.-L., 2002. Validation of the land-surface temperature products retrieved from Terra Moderate Resolution Imaging Spectroradiometer data. Remote Sens. Environ. 83, 163-180.

Waring, R.H., Franklin, J.F., 1979. Evergreen coniferous forests of the Pacific Northwest. Science 204, 1380-1386.

Watts, C.J., Scott, R.L., Garatuza-Payan, J., Rodriguez, J.C., Prueger, J., Kustas, W., Douglas, M., 2007. Changes in vegetation condition and surface fluxes during NAME 2004. J. Climate 20, 1810-1820.

Wofsy, S.C., Goulden, M.L., Munger, J.W., Fan, S.-M., Bakwin, P.S., Daube, B.C., Bassow, S.L., Bazzaz, F.A., 1993. Net exchange of $\mathrm{CO}_{2}$ in a mid-latitude forest. Science 260, 1314-1317.

Wylie, B.K., Fosnight, E.A., Gilmanov, T.G., Frank, A.B., Morgan, J.A., et al., 2007. Adaptive data-driven models for estimating carbon fluxes in the Northern Great Plains. Remote Sens. Environ. 106, 399-413.

Xiao, J., Moody, A., 2004. Photosynthetic activity of US biomes: responses to the spatial variability and seasonality of precipitation and temperature. Global Change Biol. 10, 437-451.

Xiao, J., Moody, A., 2005. A comparison of methods for estimating fractional green vegetation cover within a dsertto-upland transition zone in central New Mexico, USA. Remote Sens. Environ. 98, 237-250.

Xiao, X., Zhang, Q., Saleska, S., Hutyra, L., Camargo, P.D., et al., 2005. Satellite-based modeling of gross primary production in a seasonally moist tropical evergreen forest. Remote Sens. Environ. 94, 105-122.

$\mathrm{Xu}$, L., Baldocchi, D.D., 2004. Seasonal variation in carbon dioxide exchange over a Mediterranean annual grassland in California. Agric. For. Meteorol. 123, 79-96.

Yamaji, T., Sakai, T., Endo, T., Baruah, P.J., Akiyama, T., Saigusa, N., Nakai, Y., Kitamura, K., Ishizuka, M., Yasuoka, Y., 2008. Scaling-up technique for net ecosystem productivity of deciduous broadleaved forests in Japan using MODIS data. Ecol. Res. 23, 765-775.

Yang, L., Huang, C., Homer, C., Wylie, B.K., Coan, M.J., 2003. An approach for mapping large-area impervious surfaces: synergistic use of Landsat-7 ETM+ and high spatial resolution imagery. Can. J. Remote Sens. 29, 230-240.

Yang, F., Ichii, K., White, M.A., Hashimoto, H., Michaelis, A.R., Votava, P., Zhu, A.-X., Huete, A., Running, S.W., Nemani, R.R., 2007. Developing a continental-scale measure of gross primary production by combining MODIS and AmeriFlux data through support machine approach. Remote Sens. Environ. 110, 109-122.

Zhao, M., Heinsch, F.A., Nemani, R.R., Running, S.W., 2005. Improvements of the MODIS terrestrial gross and net primary production global data set. Remote Sens. Environ. 95, 164-175.

Zhuang, Q., McGuire, A.D., Melillo, J.M., Clein, J.S., Dargaville, R.J., Kicklighter, D.W., Myneni, R.B., Dong, J., Romanovsky, V.E., Harden, J., Hobbie, J.E., 2003. Carbon cycling in extratropical terrestrial ecosystems of the Northern Hemisphere during the 20th Century: a modeling analysis of the influences of soil thermal dynamics. Tellus 55B, 751-776. 